\title{
Amyloid $\beta$ aggregation inhibitory activity of triterpene saponins from the cactus Stenocereus pruinosus
}

\author{
Koji Fujihara ${ }^{1} \cdot$ Takuya Shimoyama $^{1} \cdot$ Ryo Kawazu $^{1} \cdot$ Hiroaki Sasaki $^{1} \cdot$ Kiyotaka Koyama $^{1} \cdot$ Kunio Takahashi $^{1}$. \\ Kaoru Kinoshita' ${ }^{1}$ (1)
}

Received: 18 September 2020 / Accepted: 22 October 2020 / Published online: 24 November 2020

(c) The Japanese Society of Pharmacognosy 2020

\section{Abstract}

Six new triterpene saponins $(\mathbf{1}-\mathbf{5}, 7)$ and 3 known saponins $(\mathbf{6 , 8 , 9})$ were isolated from $\mathrm{MeOH}$ extracts of the cactus Stenocereus pruinosus. The structures of the isolated saponins were elucidated using MS, IR, and comprehensive NMR measurements. To develop drugs for treating Alzheimer's disease (AD) on the basis of the amyloid cascade hypothesis, the isolated saponins were evaluated for inhibition of BACE1 activity and amyloid beta (A $\beta)$ aggregation using thioflavin-T assay, and triterpenes as an aglycone moiety and an alkaline hydrolysate of the saponins were also evaluated. One saponin, stenoside $\mathrm{A}(7)$, exhibited inhibitory activity related to $\mathrm{A} \beta$ aggregation and its degree of $\mathrm{A} \beta$ aggregation was $40.6 \%$ at $100 \mu \mathrm{M}$.

\section{Graphic abstract}

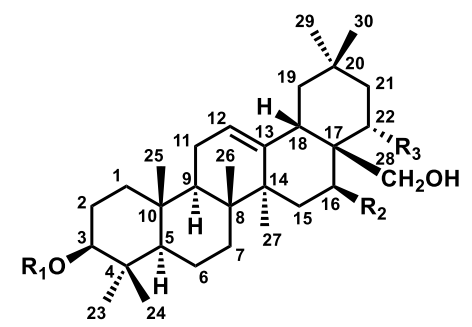

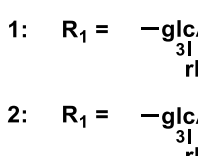

$$
\underset{31}{\text { rha }}
$$

3: $\mathbf{R}_{1}=\underset{\substack{\text { rha } \\ \text { rha }}}{\operatorname{glcA}(\mathrm{Me})}$

$\mathrm{R}_{2}=-\mathrm{OH} \quad \mathrm{R}_{3}=-\mathrm{O}-\mathrm{glc}{ }^{4}-\mathrm{rha}$

$\underset{31}{\text { rha }}$

$\mathrm{R}_{2}=-\mathrm{OH} \quad \mathrm{R}_{3}=-\mathrm{H}$

4: $R_{1}=\underset{\text { rha }}{\operatorname{glcA}(M e)^{2}}-g \mid c$

$\mathrm{R}_{2}=-\mathrm{OH} \quad \mathrm{R}_{3}=-\mathrm{H}$

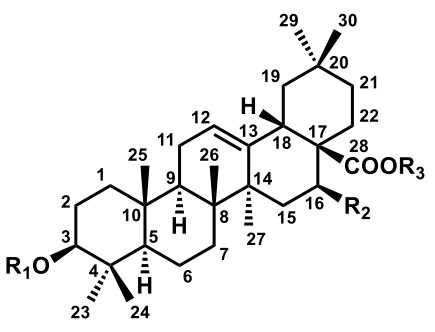

5: $\quad R_{1}=-g \mid c A$

$\mathbf{R}_{\mathbf{2}}=-\mathrm{OH} \quad \mathbf{R}_{\mathbf{3}}=-\mathrm{rha}$

6: $\quad R_{1}=-g_{3 !} \mid c A-x y l$

$\mathbf{R}_{2}=-\mathrm{H} \quad \mathbf{R}_{\mathbf{3}}=-\mathrm{glc}$

7: $\quad R_{1}=-g_{31}|c| 2-g l c$

$R_{2}=-H \quad R_{3}=-g \mid c-x y l$

8: $R_{1}=-\underset{3 \mid}{g \mid c A}$

$R_{2}=-H \quad R_{3}=-g l c$

9: $\quad \mathrm{R}_{1}=-\underset{3 !}{\operatorname{glcA}}(\mathrm{Me})$

$R_{2}=-H \quad R_{3}=-g l c$

Keywords Cactus $\cdot$ Stenocereus pruinosus $\cdot$ Saponins $\cdot$ Alzheimer's disease $\cdot$ Amyloid beta $\cdot$ BACE1

Electronic supplementary material The online version of this article (https://doi.org/10.1007/s11418-020-01463-0) contains supplementary material, which is available to authorized users.

Kaoru Kinoshita

kaoru@my-pharm.ac.jp

Extended author information available on the last page of the article

\section{Introduction}

Cacti range mainly throughout South America to the southern areas of North America, regions that have two seasons clearly distinguishable as rainy and dry. Cactus plants are 
divided into primarily three forms, known as arborescent cacti, columnar cacti, and globular cacti. Stenocereus pruinosus (Otto) Buxb. belongs to columnar cacti widely distributed in semi-arid areas of the South East of Mexico, intensely managed in Central Mexico to gather its fruits, and sometimes cultivated as home garden [1]. The height of $S$. pruinosus is up to $8 \mathrm{~m}$, blanches are green with 5-8 ribs, and flowers are infundibuliform $7-10 \mathrm{~cm}$ in length growing in the blanch apexes with green-brownish external tepals and white internal tepals which are produced 2 or 3 years after being planted $[1,2]$. The constituents of cacti have been investigated by Djerassi and co-workers, who reported a lot of triterpenoid sapogenins in an acid-hydrolyzed saponinrich extract from many cacti and one of their works revealed S. pruinosus contained oleanolic acid [3]. Considering those reports, we had been further investigating triterpene sapogenins from many cacti and discovered that $S$. pruinosus contained erythrodiol, longispinogenin and $3 \beta$-hydroxy-

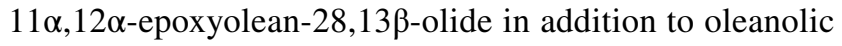
acid from hydrolysate of $\mathrm{MeOH}$ extract of S. pruinosus [4]. Now, we have been investigating triterpene saponins from cacti for several decades [5-12] and reported the identification of numerous saponins exhibiting bioactivities such as anti-type I allergy activity [7], inhibition or promotion of melanin synthesis [5], inhibition of amyloid $\beta(\mathrm{A} \beta)$ aggregation, and protective effects on SH-SY5Y cells against $\mathrm{A} \beta$-associated toxicity [6].

Saponins are well-known phytochemicals that are comprised of two parts, an aglycone moiety and a sugar moiety. The activities of saponins have been well studied and include anti-inflammatory, anti-tumor, anti-obesity, anti-angiogenesis, anti-allergic, anti-microbial, and anti-Alzheimer's disease (AD) $[13,14]$. In particular, our group found that saponins from cacti have unique structures [5-12] that have not been adequately investigated.

$\mathrm{AD}$ is a globally significant disease that involves cognitive and locomotor disorders resulting from progressive neurodegeneration. It is frequently said that $\mathrm{AD}$ has a complex pathogenesis that involves several key steps: $A \beta$ production, $A \beta$ aggregation, and neural cell death. $A \beta$ production is caused by the cleavage of amyloid precursor protein (APP) by the action of the enzymes $\beta$-secretase and $\gamma$-secretase $[15,16]$. As the concentration of $A \beta$ increases, it begins to aggregate and form $A \beta$-oligomers, $A \beta$-fibrils, and in most cases, senile plaques. Once $A \beta$ aggregation occurs, neural cell death gradually begins $[17,18]$. This step also involves complex pathways that consist of synaptic and neuritic injury, altered ionic homeostasis, oxidative damage, altered kinase/phosphatase activity, neurofibrillary tangles, and microglial and astrocytic activation [19]. The prevention of neural cell death is clearly important, but $\mathrm{A} \beta$ production and aggregation are also important for the $\mathrm{A} \beta$-associated steps that represent the upstream pathways of $\mathrm{AD}$ pathogenesis. As such, many groups have explored numerous candidate phytochemicals from natural resources for inhibition of $A \beta$ production and aggregation [19-22]. A recent report identified saponins as a class of candidate phytochemicals [23, 24].

Here, we report the isolation and structure elucidation of various saponins (1-9), including 6 new compounds $(\mathbf{1 - 5 , 7 )}$ and 3 known saponins $(\mathbf{6 , 8}-\mathbf{9})$, isolated from the cactus Stenocereus pruinosus (Otto) Buxb. (Fig. 1). We also evaluated the activity of these compounds in terms of inhibition of $\mathrm{A} \beta$ aggregation and BACE1 activity. Our data revealed two particularly remarkable findings. First, compounds $\mathbf{1}$ and 6-7 have a rare linkage of a sugar unit. Compound $\mathbf{1}$
Fig. 1 Structures of compounds (1-9) Isolated from Stenocereus pruinosus

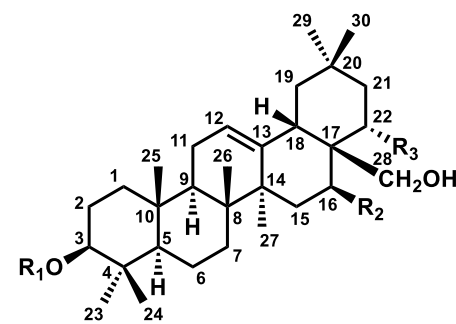

1:

$\mathbf{R}_{1}=\underset{\substack{\text { rha } \\ \text { rha }}}{\text { glcA }}$

2: $\quad R_{1}=\underset{\substack{\text { ril } \\ \text { rha }}}{\text { glcA }}$

3: $\quad R_{1}=-\underset{31}{g l c A}(M e)$

4: $\quad R_{1}=\underset{\substack{31 \\ \text { rha }}}{\operatorname{glcA}(M e)^{2}}-g l c$

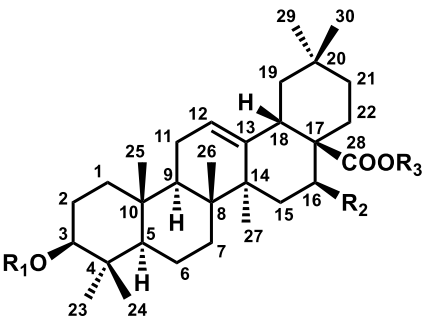

5:

$R_{1}=-\underset{31}{g l c A}$

6: $R_{1}=-g_{3 \mid} \mid A^{2}-x y l$

7: $\quad R_{1}=-g \mid c A^{2}-g l c$

rha

8: $\quad R_{1}=-$ glcA

9: $\quad R_{1}=-\underset{31}{\operatorname{glcA}}(\mathrm{Me})$

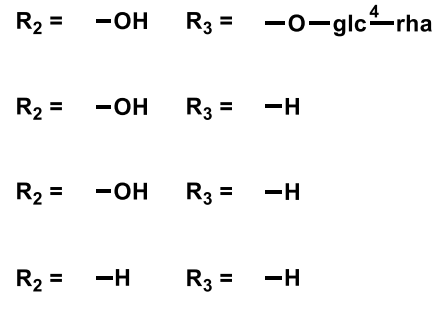

$R_{2}=-H \quad R_{3}=-H$

$\mathrm{R}_{\mathbf{2}}=-\mathrm{OH} \quad \mathrm{R}_{\mathbf{3}}=-$ rha

$R_{2}=-H \quad R_{3}=-g l c$

$R_{2}=-H \quad R_{3}=-g l c-x y l$

$\mathbf{R}_{2}=-\mathrm{H} \quad \mathbf{R}_{3}=-\mathrm{glc}$

$R_{2}=-H \quad R_{3}=-g l c$ 
has a glucopyranosyl unit that binds to the $\mathrm{C}-22$ region of its aglycone, whereas 6 has a xylopyranosyl unit that binds to the $\mathrm{C}-3^{\prime}$ of glucuronic acid, and $\mathbf{7}$ also has a xylopyranosyl unit that binds to the C-2"' of glucose binding to C-28 of its aglycone. Second, compounds $2-\mathbf{4}$ have rare triterpenes for cactus plants, longispinogenin and erythrodiol, as aglycones. These are the first reports of isolation of such saponins from columnar cactus plants.

\section{Results and discussion}

Dried Stenocereus pruinosus was extracted repeatedly with chloroform and then with methanol. The methanol extract was separated by silica gel and octadecyl silyl silica gel (ODS) column chromatography, yielding chichipenoside D (1), longispinoside A (2), longispinoside A methyl ester (3), erythronoside A (4), cochalinoside C $(5)$, oleanolic acid 3-O- $\beta$-D-xylopyranosyl- $(1 \rightarrow 2)-\alpha-\mathrm{L}-$ rhamnopyranosyl-( $1 \rightarrow 3)-\beta$-D-glucuronopyranosyl-28-O$\beta$-D-glucopyranoside (6), Stenoside A (7), oleanolic acid 3 - $O$ - $\alpha$-L-rhamnopyranosyl- $(1 \rightarrow 3)-\beta$-D-glucuronopyranosyl28-O- $\beta$-D-glucopyranoside $(\mathbf{8})$ and oleanolic acid 3 - $O$ - $\alpha$-L-rhamnopyranosyl- $(1 \rightarrow 3)$ - $\beta$-D-6'- $O$-methyl glucuronopyranosyl-28-O- $\beta$-D-glucopyranoside (9) (Fig. 1). The structures of compounds $\mathbf{1}-\mathbf{9}$ were determined by mass and NMR spectroscopy using ${ }^{1} \mathrm{H}$ - and ${ }^{13} \mathrm{C}-\mathrm{NMR}$, DEPT, HMQC, HMBC, ${ }^{1} \mathrm{H}-{ }^{1} \mathrm{H}$ COSY or DQF-COSY, HSQCTOCSY, phase-sensitive TOCSY and phase-sensitive NOESY experiments.

Compound 1 (16.7 mg, 0.003\%) was obtained as a colorless amorphous powder, and its optical rotation value was elucidated as $[\alpha]^{21}{ }_{\mathrm{D}}-28.0(c 0.25, \mathrm{MeOH})$. The molecular formula of 1 was elucidated to be $\mathrm{C}_{54} \mathrm{H}_{88} \mathrm{O}_{23}$ using negative HRFABMS $\left(\mathrm{m} / z, 1103.5640,[\mathrm{M}-\mathrm{H}]^{-}\right)$. The IR spectrum of 1 showed absorptions at $3385 \mathrm{~cm}^{-1}$ (hydroxy) and $1714 \mathrm{~cm}^{-1}$ (carbonyl). The signal patterns of the ${ }^{1} \mathrm{H}$ - and ${ }^{13} \mathrm{C}$-NMR spectral data indicated that the aglycone moiety was an oleanane-type triterpene. The ${ }^{1} \mathrm{H}$ - and ${ }^{13} \mathrm{C}-\mathrm{NMR}$ spectral data indicated the presence of seven methyl groups in the aglycone, characterized by signals at $\left[\delta_{\mathrm{H}} 0.76,0.87\right.$, $0.90,0.96$ and 1.16 (each $3 \mathrm{H}, \mathrm{s})$, and $\left.\delta_{\mathrm{H}} 0.88(6 \mathrm{H}, \mathrm{s})\right]$, and 15.3, 16.4, 16.6, 24.4, 26.8, 27.6, and $32.8\left(\right.$ each $\left.\mathrm{CH}_{3}\right)$. The presence of signals at $\delta_{\mathrm{C}} 64.5(\mathrm{CH})$ and $\delta_{\mathrm{H}} 4.42(1 \mathrm{H}$, br s), $\delta_{\mathrm{C}} 77.9(\mathrm{CH})$ and $\delta_{\mathrm{H}} 4.25(1 \mathrm{H}, \mathrm{dd}, J=12.6,4.5 \mathrm{~Hz}), \delta_{\mathrm{C}} 56.7$ $\left(\mathrm{CH}_{2}\right)$ and $\left[\delta_{\mathrm{H}} 3.33(1 \mathrm{H}, \mathrm{o})\right.$, and $\left.\delta_{\mathrm{H}} 3.77(1 \mathrm{H}, \mathrm{m})\right]$ indicated that the aglycone had three hydroxyl groups, except in the C-3 region $\left[\delta_{\mathrm{C}} 88.1(\mathrm{CH})\right.$ and $\delta_{\mathrm{H}} 3.02(1 \mathrm{H}, \mathrm{dd}, J=11.3$, $3.2 \mathrm{~Hz}$ )], and the stereochemistry of $3-\mathrm{OH}$ was determined as a $\beta$-configuration by its ${ }^{3} J_{\mathrm{H} 2 / \mathrm{H} 3}$ coupling constants of $11.3 \mathrm{~Hz}$. Further analysis of the aglycone of $\mathbf{1}$ primarily using HMQC, HMBC, DQF-COSY, phase-sensitive NOESY spectral correlations, and complementarily using phase-sensitive TOCSY spectral correlations, revealed four hydroxyl groups assigned at C-3 $\left(\delta_{\mathrm{C}} 88.1\right), \mathrm{C}-16\left(\delta_{\mathrm{C}} 64.5\right), \mathrm{C}-22\left(\delta_{\mathrm{C}}\right.$ 77.9), and $\mathrm{C}-28\left(\delta_{\mathrm{C}} 56.7\right)$. The NOESY correlations between $\delta_{\mathrm{H}} 1.16\left(\mathrm{H}_{3}-27\right)$ and $\delta_{\mathrm{H}} 4.42(\mathrm{H}-16), \delta_{\mathrm{H}} 3.33,3.77(\mathrm{H}-28)$ and $\delta_{\mathrm{H}} 0.90(\mathrm{H}-26)$, and $\delta_{\mathrm{H}} 4.25(\mathrm{H}-22)$ and $\delta_{\mathrm{H}} 2.50(\mathrm{H}-18)$ supported the stereochemistries of $16-\mathrm{OH}$ and $22-\mathrm{OH}$ as $\beta$-configuration and $\alpha$-configuration, respectively (Fig. 2). The signals at $\delta_{\mathrm{H}} 1.56(1 \mathrm{H}$, br t, $J=12.6 \mathrm{~Hz}, \mathrm{H}-21 \alpha), \delta_{\mathrm{H}}$ $1.68(1 \mathrm{H}, \mathrm{br} d, J=12.6 \mathrm{~Hz}, \mathrm{H}-21 \beta)$ and $\delta_{\mathrm{H}} 4.25(1 \mathrm{H}, \mathrm{dd}$, $J=12.6,4.5 \mathrm{~Hz}, \mathrm{H}-22$ ) also supported the stereochemistry of 22-OH as $\alpha$-configuration by its large ${ }^{3} J_{\mathrm{H} 21 \alpha / \mathrm{H} 22}$ coupling constants of $11.3 \mathrm{~Hz}$ and small ${ }^{3} J_{\mathrm{H} 21 \beta / \mathrm{H} 22}$ coupling constants of $4.5 \mathrm{~Hz}$. These data confirmed that the aglycone of 1 was chichipegenin. The ${ }^{1} \mathrm{H}$ - and ${ }^{13} \mathrm{C}-\mathrm{NMR}$ spectra exhibited four anomeric proton signals $\left[\delta_{\mathrm{H}} 4.17(1 \mathrm{H}, \mathrm{d}, J=7.7 \mathrm{~Hz}), \delta_{\mathrm{H}} 4.33\right.$ $\left.(1 \mathrm{H}, \mathrm{d}, J=7.8 \mathrm{~Hz}), \delta_{\mathrm{H}} 4.69(1 \mathrm{H}, \mathrm{br} \mathrm{s}), \delta_{\mathrm{H}} 5.04(1 \mathrm{H}, \mathrm{br} \mathrm{s})\right]$ and carbon signals $\left[\delta_{\mathrm{C}} 100.2(\mathrm{CH}), \delta_{\mathrm{C}} 100.5(\mathrm{CH}), \delta_{\mathrm{C}} 103.3\right.$ $\left.(\mathrm{CH}), \delta_{\mathrm{C}} 105.1(\mathrm{CH})\right]$. Detailed analysis of the sugar moiety of $\mathbf{1}$ using HMQC, HMBC, DQF-COSY, HSQC-TOCSY, phase-sensitive TOCSY, and phase-sensitive NOESY experiments revealed the presence of one $\beta$-glucuronic acid, one $\beta$-glucose, and two $\alpha$-rhamnose units. The linkage of each sugar was determined by HMBC correlations.
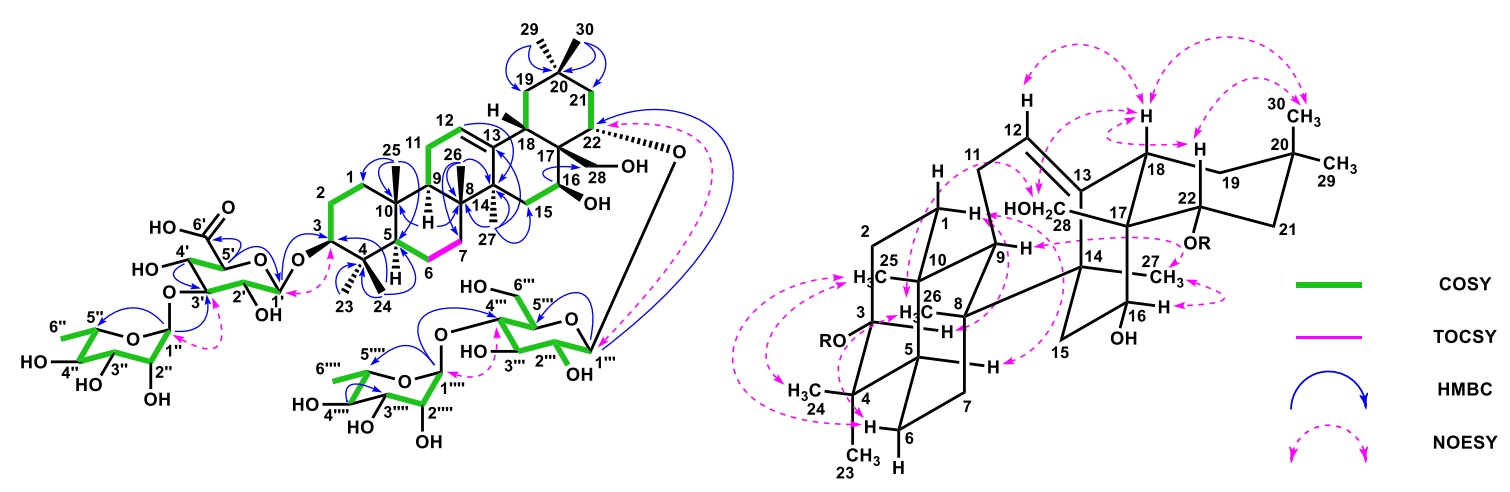

Fig. 2 HMBC, COSY, and Key NOESY correlations of $\mathbf{1}$ 
The correlation between $\mathrm{H}-1^{\prime}$ of the glucuronic acid $\left(\delta_{\mathrm{H}}\right.$ 4.17) and $C-3$ of the aglycone $\left(\delta_{C} 88.1\right)$ showed that the glucuronic acid-1 unit binds at $\mathrm{C}-3$ of the aglycone moiety. Similarly, the correlation between $\mathrm{H}-1$ " of rhamnose $\left(\delta_{\mathrm{H}}\right.$ 5.04) and C-3' of glucuronic acid $\left(\delta_{\mathrm{C}} 80.3\right)$ showed that the rhamnose- 1 unit binds at $\mathrm{C}-3^{\prime}$ of the glucuronic acid unit. In contrast, the correlation between $\mathrm{H}-1^{\prime \prime \prime}$ of glucose $\left(\delta_{\mathrm{H}}\right.$ 4.33) and C-22 of the aglycone $\left(\delta_{\mathrm{C}} 77.9\right)$ showed that the glucose- 1 unit binds at $\mathrm{C}-22$ of the aglycone moiety. Considering the chemical shift of C- $22\left(\delta_{C} 67.4\right)$ of chichipenoside $\mathrm{C}$ [5], this deshielding of $\mathrm{C}-22\left(\delta_{\mathrm{C}} 77.9\right)$ of the aglycone also supported the binding of the glucose- 1 unit at C-22 of the aglycone. In addition, the correlation between $\mathrm{H}-1^{\prime \prime \prime \prime}$ of the second rhamnose $\left(\delta_{\mathrm{H}} 4.69\right)$ and C- 4 "' of glucose $\left(\delta_{\mathrm{C}}\right.$ 76.6) indicated that the rhamnose- 1 unit binds at $\mathrm{C}-4^{\prime \prime \prime}$ of the glucose unit. These correlations are shown in Fig. 2. The absolute configuration of each sugar unit was determined by measuring the ODS HPLC retention times of the derivatives from D-glucuronic acid, D-glucose, and L-rhamnose [25]. Whereas the anomeric proton on the glucuronopyranosyl and glucopyranosyl units were determined to have a $\beta$-configuration based on the ${ }^{3} J_{\mathrm{H} 1-\mathrm{H} 2}$ values $(7.7$ and $7.8 \mathrm{~Hz}$, respectively), the anomeric protons on the two rhamnopyranosyl units were determined to have a $\alpha$-configuration based on ${ }^{1} J_{\mathrm{C} 1-\mathrm{H} 1}$ value (171.7 and $169.4 \mathrm{~Hz}$ ) [26] and three-bond strong HMBC correlations from H-1" to C-3" and C-5", and $\mathrm{H}-1^{\prime \prime \prime \prime}$ to $\mathrm{C}-3^{\prime \prime \prime \prime}$ and $\mathrm{C}-5^{\prime \prime \prime \prime}$. Its three-bond strong HMBC correlations were attributed to the dihedral angles between $\mathrm{H}-1$ and $\mathrm{C}-3, \mathrm{H}-1$ and $\mathrm{C}-5$ of rhamnose about $180^{\circ}$ [27]. Thus, compound 1 was determined chichipegenin 3-O- $\alpha$-Lrhamnopyranosyl-( $1 \rightarrow 3)-\beta$-D-glucuronopyranosyl-22- $O-\alpha-$ L-rhamnopyranosyl-( $1 \rightarrow 4)-\beta$-D-glucopyranoside and named as chichipenoside D (Fig. 2).

Compound 2 (16.0 mg, 0.003\%) was obtained as a colorless amorphous powder, and its optical rotation value was elucidated as $[\alpha]_{\mathrm{D}^{-}}^{18}-52.0(c 0.2 \mathrm{MeOH})$. The molecular formula of 2 was elucidated to be $\mathrm{C}_{42} \mathrm{H}_{68} \mathrm{O}_{13}$ using positive HRFABMS $\left(\mathrm{m} / \mathrm{z}\right.$ 803.4546, $\left.[\mathrm{M}+\mathrm{Na}]^{+}\right)$. The IR spectrum of 2 showed absorptions at $3330 \mathrm{~cm}^{-1}$ (hydroxy) and $1740 \mathrm{~cm}^{-1}$ (carbonyl). The ${ }^{1} \mathrm{H}$ - and ${ }^{13} \mathrm{C}$-NMR spectral data indicated the presence of seven methyl groups in its aglycone, characterized by signals at $\left[\delta_{\mathrm{H}} 0.75,0.87,0.90,0.96\right.$ and 1.14 (each $3 \mathrm{H}, \mathrm{s})$, and $0.84(6 \mathrm{H}, \mathrm{s})]$ and $15.3,16.316 .5$, 23.7, 26.6, 27.5, and $33.1\left(\right.$ each $\mathrm{CH}_{3}$ ). The signal patterns of the ${ }^{1} \mathrm{H}$ - and ${ }^{13} \mathrm{C}$-NMR spectral data indicated that the aglycone moiety was an oleanane-type triterpene. The presence of three sets of signals at $\delta_{\mathrm{C}} 64.5(\mathrm{CH})$ and $\delta_{\mathrm{H}} 4.06(1 \mathrm{H}$, dd, $J=12.4,4.4 \mathrm{~Hz}), \delta_{\mathrm{C}} 65.2\left(\mathrm{CH}_{2}\right)$ and $\delta_{\mathrm{H}} 3.12(1 \mathrm{H}, \mathrm{o}), 3.51$ $(1 \mathrm{H}, \mathrm{d}, J=10.2 \mathrm{~Hz})$ and $\delta_{\mathrm{C}} 88.3(\mathrm{CH})$ and $\delta_{\mathrm{H}} 3.05(1 \mathrm{H}, \mathrm{dd}$, $J=11.3,4.0 \mathrm{~Hz}$ ) indicated that the aglycone of 2 had three hydroxyl groups. Further analysis of the aglycone of $\mathbf{2}$ using HMQC, HMBC, DQF-COSY, and phase-sensitive NOESY spectral correlations assigned the three hydroxyl groups at C-3, C-16, and C-28. The NOESY correlation between $\delta_{\mathrm{H}}$ $1.14\left(\mathrm{H}_{3}-27\right)$ and $\delta_{\mathrm{H}} 4.06(\mathrm{H}-16)$ and the ${ }^{3} J_{\mathrm{H} 15 / \mathrm{H} 16}$ coupling constant of $12.4 \mathrm{~Hz}$ revealed the stereochemistry of the $16-\mathrm{OH}$ was $\beta$-configuration and confirmed that the aglycone of 2 was longispinogenin (Fig. 3). The ${ }^{1} \mathrm{H}$ - and ${ }^{13} \mathrm{C}-\mathrm{NMR}$ spectra about sugar units showed partially similar signal patterns to those of $\mathbf{1}$. Additionally considering ODS HPLC data [25] and comprehensive 2D-NMR analysis including strong three-bond HMBC correlation [27], it was revealed that the presence of two sugars, $\beta$-D-glucuronic acid and $\alpha$-Lrhamnose. It could not be performed to measure the ${ }^{1} J_{\mathrm{C} 1-\mathrm{H} 1}$ value about the anomeric protons on the rhamnopyranosyl units contained in new saponins $(\mathbf{2}-\mathbf{5 , 7})$ from $S$. pruinosus, the rhamnopyranosyl units presumably had $\alpha$-configuration because of our previous reports [5-12], their multiplicity ("br s" or "d" with small coupling constant) and their strong three-bond HMBC correlations [27]. Further analysis confirmed that compound 2 was longispinogenin 3-O- $\alpha$-Lrhamnopyranosyl-( $1 \rightarrow 3)$ - $\beta$-D-glucuronopyranoside and named as longispinoside A (Fig. 3).

Compound $\mathbf{3}$ (24.2 mg, 0.004\%) was obtained as a colorless amorphous powder, and its optical rotation value was elucidated as $[\alpha]^{19} \mathrm{D}^{-117.3}(c 0.1 \mathrm{MeOH})$. The molecular
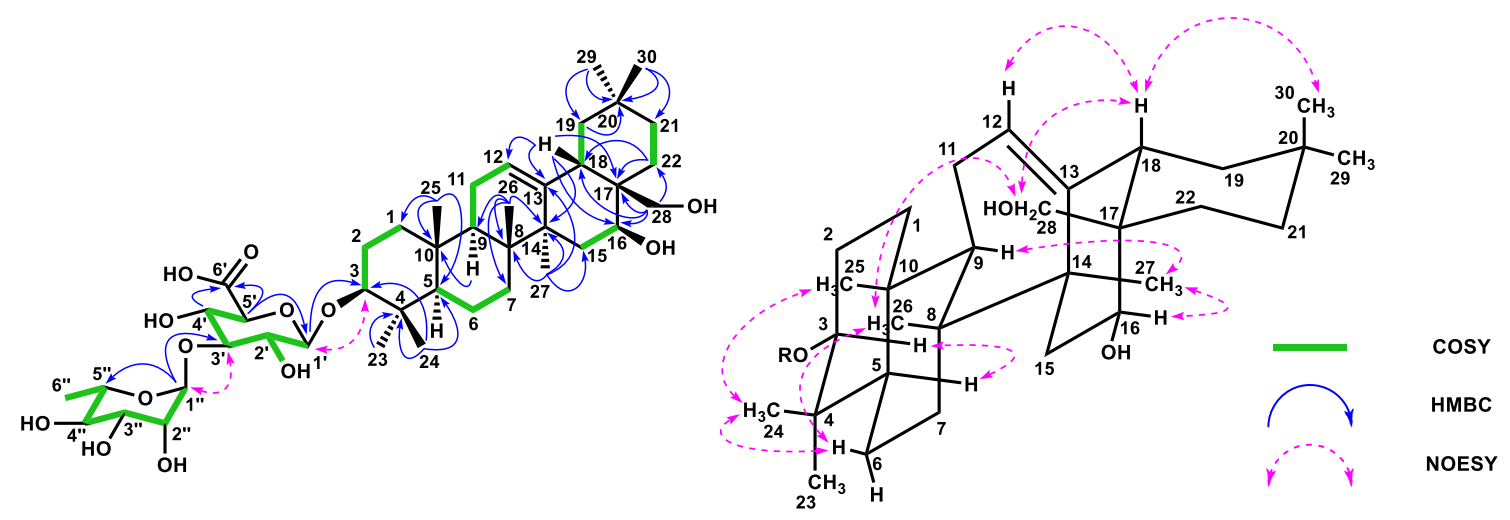

Fig. 3 HMBC, COSY, and Key NOESY correlations of 2 
formula of $\mathbf{3}$ was elucidated to be $\mathrm{C}_{43} \mathrm{H}_{70} \mathrm{O}_{13}$ using positive HRFABMS $\left(\mathrm{m} / \mathrm{z}, 795.4900,[\mathrm{M}+\mathrm{H}]^{+}\right)$. The IR spectrum of $\mathbf{3}$ showed absorptions at $3363 \mathrm{~cm}^{-1}$ (hydroxy) and $1746 \mathrm{~cm}^{-1}$ (carbonyl). The ${ }^{1} \mathrm{H}$ - and ${ }^{13} \mathrm{C}-\mathrm{NMR}$ spectral data were almost the same with 2 except for methyl signal $\left[\delta_{\mathrm{C}}\right.$ $51.9\left(\mathrm{CH}_{3}\right)$ and $\left.\delta_{\mathrm{H}} 3.65(3 \mathrm{H}, \mathrm{s})\right]$ and $\mathrm{C}-6^{\prime}$ of glucuronic acid $\left[\delta_{\mathrm{C}} 169.5(\mathrm{C})\right]$. This differences and further analysis confirmed that compound 3 was longispinogenin 3-O- $\alpha-\mathrm{L}-$ rhamnopyranosyl-( $1 \rightarrow 3)-\beta$-D-glucuronopyranoside methyl ester and named as longispinoside A methyl ester (Fig. S1).

Compound $4(9.3 \mathrm{mg}, 0.001 \%)$ was obtained as a colorless amorphous powder, and its optical rotation value was elucidated as $[\alpha]^{19}{ }^{-4} .1(c 0.1 \mathrm{MeOH})$. The molecular formula of 4 was elucidated to be $\mathrm{C}_{49} \mathrm{H}_{80} \mathrm{O}_{17}$ using positive HRFABMS $\left(m / z 941.5481,[\mathrm{M}+\mathrm{H}]^{+}\right)$. The IR spectrum of $\mathbf{4}$ showed absorptions at $3370 \mathrm{~cm}^{-1}$ (hydroxy) and $1743 \mathrm{~cm}^{-1}$ (carbonyl). The ${ }^{1} \mathrm{H}$ - and ${ }^{13} \mathrm{C}-\mathrm{NMR}$ spectral data indicated the presence of seven methyl groups in its aglycone, characterized by signals at $\left[\delta_{\mathrm{H}} 0.74,0.82,0.84,0.95\right.$ and 1.10 (each $3 \mathrm{H}, \mathrm{s}$ ), and $0.87(6 \mathrm{H}, \mathrm{s})$ ], and 15.3, 16.1, 16.4, 23.5, 25.6, 27.5, and $33.1\left(\right.$ each $\left.\mathrm{CH}_{3}\right)$. The signal patterns of the ${ }^{1} \mathrm{H}$ - and ${ }^{13} \mathrm{C}-\mathrm{NMR}$ spectral data indicated that the aglycone moiety was an oleanane-type triterpene. The presence of two sets of signals at $\left[\delta_{\mathrm{C}} 67.4\left(\mathrm{CH}_{2}\right)\right.$ and $\delta_{\mathrm{H}} 2.93(1 \mathrm{H}, \mathrm{o})$ and $3.29(1 \mathrm{H}, \mathrm{dd}, J=9.6,4.8 \mathrm{~Hz})]$ and $\left[\delta_{\mathrm{C}} 88.6(\mathrm{CH})\right.$ and $\delta_{\mathrm{H}}$ $3.04(1 \mathrm{H}, \mathrm{dd}, J=11.3,4.0 \mathrm{~Hz})]$ indicated that the aglycone of $\mathbf{4}$ had two hydroxyl groups in the C-3 region. Further analysis of the aglycone of $\mathbf{4}$ using HMQC, HMBC, DQFCOSY, phase-sensitive TOCSY, and phase-sensitive NOESY spectral correlations assigned the two hydroxy groups at $\mathrm{C}-3$ and C-28, which indicated that the aglycone of $\mathbf{4}$ was erythrodiol (Fig. 4). The ${ }^{1} \mathrm{H}$ - and ${ }^{13} \mathrm{C}-\mathrm{NMR}$ spectra showed three anomeric proton signals $\left[\delta_{\mathrm{H}} 4.43(1 \mathrm{H}, \mathrm{d}, J=7.9 \mathrm{~Hz})\right.$, $\left.\delta_{\mathrm{H}} 4.52(1 \mathrm{H}, \mathrm{d}, J=8.3 \mathrm{~Hz}), \delta_{\mathrm{H}} 4.94(1 \mathrm{H}, \mathrm{br} \mathrm{s})\right]$ and carbon signals $\left[\delta_{\mathrm{C}} 100.5(\mathrm{CH}), \delta_{\mathrm{C}} 101.6(\mathrm{CH}), \delta_{\mathrm{C}} 103.1(\mathrm{CH})\right]$.
Detailed analysis of the sugar moiety of $\mathbf{4}$ using HMQC, HMBC, DQF-COSY, HSQC-TOCSY, phase-sensitive TOCSY, and phase-sensitive NOESY experiments revealed the presence of one $\beta$-glucuronic acid, one $\beta$-glucose, and one $\alpha$-rhamnose unit, and the signals at $\delta_{\mathrm{H}} 3.65(3 \mathrm{H}, \mathrm{s})$ and $\delta_{\mathrm{C}} 169.5$ indicated the presence of glucuronic acid methyl ester instead of glucuronic acid. The linkage of each sugar was determined by HMBC correlations and the correlations indicated that the glucuronic acid- 1 unit binds at C-3 of the aglycone moiety, the glucose unit binds at C-2' of the glucuronic acid methyl ester, and the rhamnose- 1 unit binds at C-3' of the glucuronic acid methyl ester (Fig. 4). The sugar units were determined as $\beta$-D-glucuronic acid, $\alpha$-L-rhamnose, and $\beta$-D-glucose by the same method as compound 2 [25, 27]. Thus, compound 4 was determined erythrodiol $3-O-\beta$-Dglucopyranosyl-( $1 \rightarrow 2)$-[ $\alpha$-L-rhamnopyranosyl-( $1 \rightarrow 3)]$ ]- $\beta$-Dglucuronopyranoside methyl ester and named as erythronoside A methyl ester (Fig. 4).

Compound 5 (27.5 mg, 0.004\%) was obtained as a colorless amorphous powder, and its optical rotation value was elucidated as $[\alpha]^{22}{ }_{\mathrm{D}^{-}}-28.8(c 0.25 \mathrm{MeOH})$. The molecular formula of 5 was elucidated to be $\mathrm{C}_{48} \mathrm{H}_{76} \mathrm{O}_{18}$ using negative HRFABMS $\left(\mathrm{m} / \mathrm{z}\right.$ 939.4952, [M-H] $\left.{ }^{-}\right)$. The IR spectrum of $\mathbf{5}$ showed absorptions at $3370 \mathrm{~cm}^{-1}$ (hydroxy) and $1710 \mathrm{~cm}^{-1}$ (carbonyl). The ${ }^{1} \mathrm{H}$ - and ${ }^{13} \mathrm{C}-\mathrm{NMR}$ spectral data indicated the presence of seven methyl groups in its aglycone, characterized by signals at $\delta_{\mathrm{H}} 0.69,0.75,0.84,0.90,0.92,0.95$, and $1.13($ each $3 \mathrm{H}, \mathrm{s})$ and $\delta_{\mathrm{C}} 15.1,16.4,16.8,23.7,26.7,27.5$, and $32.7\left(\right.$ each $\left.\mathrm{CH}_{3}\right)$. The signal patterns of the ${ }^{1} \mathrm{H}$ - and ${ }^{13} \mathrm{C}$ NMR spectral data indicated that the aglycone moiety was an oleanane-type triterpene. The presence of a signal at $\delta_{\mathrm{C}}$ $62.7(\mathrm{CH})$ and $\delta_{\mathrm{H}} 4.06(1 \mathrm{H}, \mathrm{t}$-like, $J=11.8 \mathrm{~Hz})$ indicated that the aglycone of $\mathbf{5}$ had one hydroxyl group excepting the $\mathrm{C}-3$ region $\left[\delta_{\mathrm{C}} 88.1(\mathrm{CH})\right.$ and $\left.\delta_{\mathrm{H}} 3.03(1 \mathrm{H}, \mathrm{dd}, J=9.9,3.8 \mathrm{~Hz})\right]$. Further analysis of the aglycone of $\mathbf{5}$ using HMQC, HMBC,
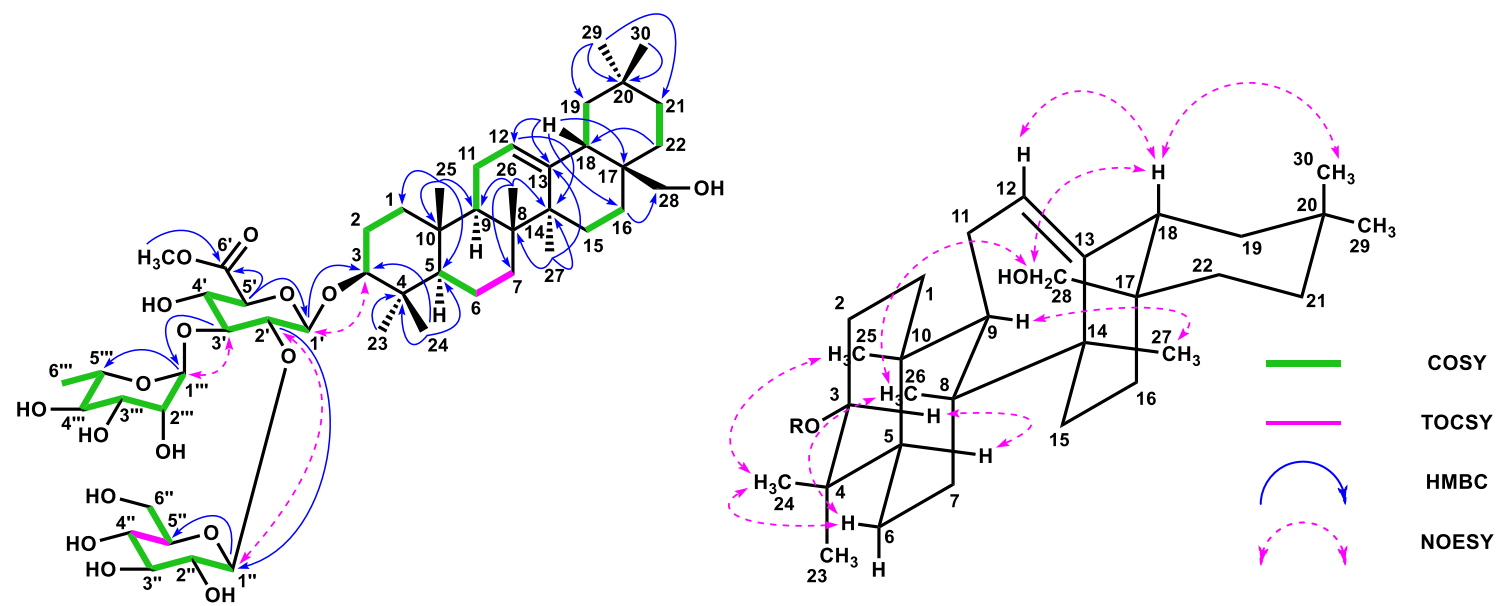

Fig. 4 HMBC, COSY, and Key NOESY correlations of 4 
DQF-COSY, phase-sensitive TOCSY, and phase-sensitive NOESY spectral correlations assigned the two hydroxy groups at $\mathrm{C}-3$ and $\mathrm{C}-16$. The stereochemistry of $16-\mathrm{OH}$ was revealed as $\beta$-configuration by NOESY correlations and its ${ }^{3} J_{\mathrm{H} 15 / \mathrm{H} 16}$ coupling constant of $12.6 \mathrm{~Hz}$, which indicated the aglycone of 5 was cochalic acid (Fig. 5). The ${ }^{1} \mathrm{H}$ - and ${ }^{13} \mathrm{C}$ NMR spectra further indicated the presence of the same sugar moiety with 2 and another anomeric signals $\left[\delta_{\mathrm{H}} 5.74\right.$ $(1 \mathrm{H}, \mathrm{d}, 1.1)$ and $\left.\delta_{\mathrm{C}} 93.3(\mathrm{CH})\right]$. Further analysis revealed the presence of another rhamnose unit binding at C-28 of the aglycone. The sugar units were determined as $\beta$-D-glucuronic acid and $\alpha$-L-rhamnose by the same method as compound $\mathbf{2}$ $[25,27]$. Thus, compound 5 was determined cochalic acid $3-O-\alpha-\mathrm{L}-$ rhamnopyranosyl-( $1 \rightarrow 3)-\beta$-D-glucuronopyranosyl$28-O-\alpha$-L-rhamnopyranoside and named as cochalinoside $\mathrm{C}$ (Fig. 5).

Compound 7 (28.9 mg, 0.005\%) was obtained as a colorless amorphous powder, and its optical rotation value was elucidated as $[\alpha]_{\mathrm{D}}^{19}-8.6(c 0.1 \mathrm{MeOH})$. The molecular formula of 7 was elucidated to be $\mathrm{C}_{59} \mathrm{H}_{94} \mathrm{O}_{27}$ using positive HRFABMS $\left(\mathrm{m} / \mathrm{z}, 1273.5620,[\mathrm{M}+\mathrm{K}]^{+}\right)$. The IR spectrum of 7 showed absorptions at $3372 \mathrm{~cm}^{-1}$ (hydroxy) and $1732 \mathrm{~cm}^{-1}$ (carbonyl). The ${ }^{1} \mathrm{H}$ - and ${ }^{13} \mathrm{C}-\mathrm{NMR}$ spectral data indicated that the aglycone was oleanolic acid, the presence of the same sugar moiety with $\mathbf{4}$ except for methyl ester, and the presence of two other sugar units. Further analysis revealed the presence of one glucose unit binding at C-28 of the aglycone and one xylose unit binding at C-2"'"' of the glucose unit (Fig. S3). The sugar units were determined as $\beta$-D-glucuronic acid, $\alpha$-L-rhamnose, $\beta$-D-glucose and $\beta$-D-xylose by the same method as compound 2 [25, 27]. Thus, compound 7 was determined oleanolic acid 3-O- $\beta$-Dglucopyranosyl- $(1 \rightarrow 2)$-[ $\alpha$-L-rhamnopyranosyl- $(1 \rightarrow 3)]-\beta$-Dglucuronopyranosyl-28- $O$ - $\beta$-D-xylopyranosyl- $(1 \rightarrow 2)-\beta$-Dglucopyranoside and named as stenoside A (Fig. S3).

Compound $\mathbf{6}$ was analyzed in the same way as described above and elucidated as known one, oleanolic acid 3-O- $\beta$ D-xylopyranosyl-( $(1 \rightarrow 2)-\alpha$-L-rhamnopyranosyl- $(1 \rightarrow 3)-\beta$-D- glucuronopyranosyl-28- $O-\beta$-D-glucopyranoside [28]. The 2D-correlations and completed assignment were shown in Fig. S2 and Table S1.

Compounds 8 and 9 were identified as oleanolic acid 3- $O$ - $\alpha$-L-rhamnopyranosyl-( $1 \rightarrow 3)-\beta$-D-glucuronopyranosyl$28-O-\beta$-D-glucopyranoside $(8)$ and oleanolic acid 3- $O$ - $\alpha$-L-rhamnopyranosyl- $(1 \rightarrow 3)-\beta$-D- $6^{\prime}-O$-methyl glucuronopyranosyl-28- $O$ - $\beta$-D-glucopyranoside (9) by comparing their spectroscopic data with published data $[29,30]$.

Some of isolated saponins $(\mathbf{1}-\mathbf{4 , 7 - 8})$, hydrolysate of 8 (8a), and oleanolic acid as the aglycone moiety of $6-9$ were evaluated the inhibition of $A \beta$ aggregation using a Th-T assay and inhibition of BACE1 activity (Table 1). A newly isolated saponin (7) exhibited $\mathrm{A} \beta$ aggregation inhibitory activity ( $40.6 \%$ at $100 \mu \mathrm{M})$, and compounds 1 and $\mathbf{4}$ exhibited moderate activity $(66.4 \%$ and $70.0 \%$, respectively, at $100 \mu \mathrm{M})$. The activity of $\mathbf{8 a}$ was almost same level as $\mathbf{8}$ at $100 \mu \mathrm{M}$.

A preliminary SAR suggested that glycosylations at C-28 position of the oleanolic acid like $\mathbf{7}$ increased its inhibitory activity comparing with a glycosylation at C-28 position of the oleanolic acid like 8 . In addition to this, glycosylations at C-3 position of the oleanolic acid hardly had any effects on its activity in the case of $\mathbf{8 a}$. According to these results, glycosylations at $\mathrm{C}-28$ might be important for $\mathrm{A} \beta$ aggregation inhibitory activity.

Chichipenoside $\mathrm{C}$, chichipegenin 3-O- $\alpha-\mathrm{L}-$ rhamnopyranosyl-( $1 \rightarrow 2)-\beta$-D-glucopyranosyl- $(1 \rightarrow 2)-\beta$-Dglucuronopyranoside, which has already isolated from Polaskia chichipe [5], exhibited $\mathrm{A} \beta$ aggregation inhibitory activity at the same level as chichipegenin (chichpenoside C; $43.8 \%$, chichipegenin; $39.2 \%$, respectively, at $25 \mu \mathrm{M}$ ) [6], while chichipenoside $\mathrm{D}$ exhibited weaker activity than that of chichipenoside $\mathrm{C}$ and chichipegenin. Its SAR suggested that glycosylations at $\mathrm{C}-22$ position of the chichipegenin attenuated $A \beta$ aggregation inhibitory activity. It would be expected that saponins mono-glycosylated at C-22 position

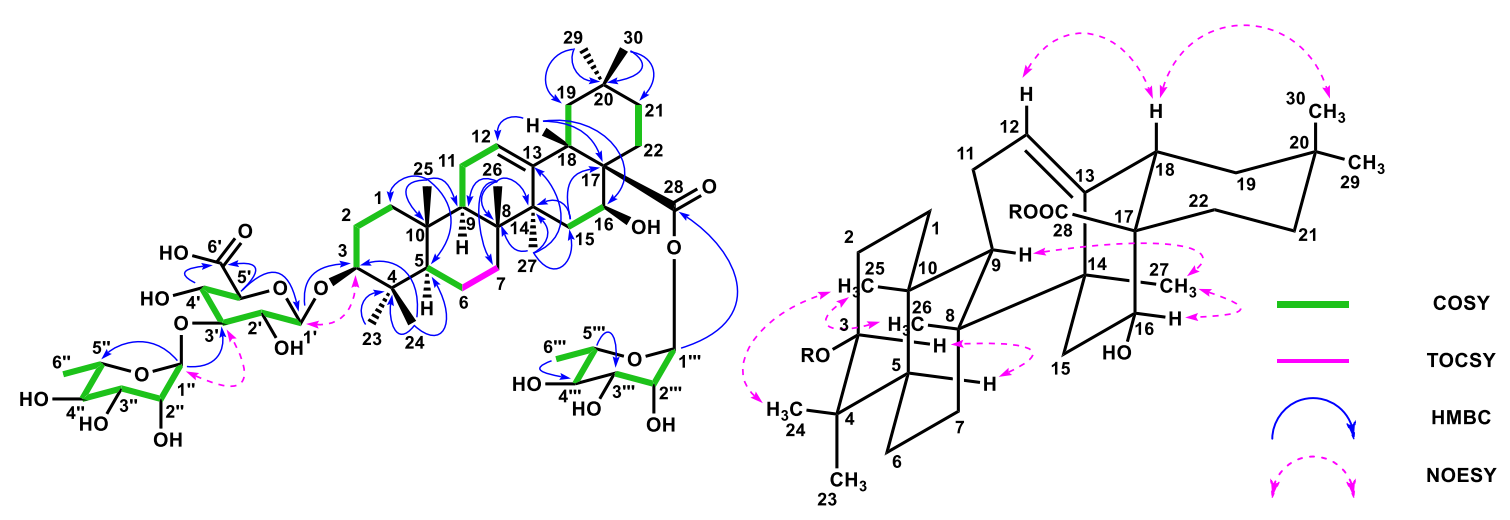

Fig. 5 HMBC, COSY, and Key NOESY correlations of $\mathbf{5}$ 
Table 1 Assay results of the isolated and associated compounds against $\mathrm{A} \beta$ aggregation and $\mathrm{BACE} 1$ activity

\begin{tabular}{llll}
\hline Compound & Conc. $(\mu \mathrm{M})$ & $\begin{array}{l}\mathrm{A} \beta \text { aggregation } \\
(\%)\end{array}$ & $\begin{array}{l}\text { BACE1 inhibition } \\
(\%)\end{array}$ \\
\hline $\mathbf{1}$ & 100 & $66.4 \pm 6.4$ & $\mathrm{NA}^{\mathrm{b}}$ \\
$\mathbf{2}$ & 100 & $92.5 \pm 7.3$ & $\mathrm{NA}^{\mathrm{b}}$ \\
$\mathbf{3}$ & 100 & $77.3 \pm 4.1$ & $\mathrm{NA}^{\mathrm{b}}$ \\
$\mathbf{4}$ & 100 & $70.0 \pm 0.7$ & $\mathrm{NA}^{\mathrm{b}}$ \\
$\mathbf{5}$ & 100 & $\mathrm{ND}^{\mathrm{a}}$ & $\mathrm{ND}^{\mathrm{a}}$ \\
$\mathbf{6}$ & 100 & $\mathrm{ND}^{\mathrm{a}}$ & $\mathrm{ND}^{\mathrm{a}}$ \\
$\mathbf{7}$ & 100 & $40.6 \pm 5.8$ & $\mathrm{NA}^{\mathrm{b}}$ \\
$\mathbf{8}$ & 100 & $81.4 \pm 3.7$ & $\mathrm{NA}^{\mathrm{b}}$ \\
$\mathbf{9}$ & 100 & $\mathrm{ND}^{\mathrm{a}}$ & $\mathrm{ND}^{\mathrm{a}}$ \\
$\mathbf{8 a}$ & 100 & $95.4 \pm 15.4$ & $\mathrm{NA}^{\mathrm{b}}$ \\
Oleanolic acid & 100 & $78.8 \pm 7.8$ & $45.3 \pm 23.2$ \\
Cochalic acid & 100 & $\mathrm{ND}^{\mathrm{a}}$ & $35.8 \pm 8.8$ \\
Chichipegenin & 100 & $\mathrm{ND}^{\mathrm{a}}$ & $\mathrm{NA}^{\mathrm{b}}$ \\
Myricetin & 25 & $23.4 \pm 2.2$ & \\
Inhibitor IV & 10 & & $69.1 \pm 13.7$ \\
\hline
\end{tabular}

Data are shown as mean with standard errors $(n=3)$

${ }^{\mathrm{a}} \mathrm{ND}=$ no data

${ }^{\mathrm{b}} \mathrm{NA}=$ not active

of the chichipegenin are isolated and tested for inhibitory activity related to $A \beta$ aggregation.

In contrast, saponins $(\mathbf{1 - 4 , 7 - 8})$ and hydrolysate of $8(\mathbf{8 a})$ did not exhibit any BACE1 inhibitory activities at $100 \mu \mathrm{M}$, while oleanolic acid exhibited moderate activity $(45.3 \%$ at $100 \mu \mathrm{M})$. Its $\mathrm{IC}_{50}$ value was previously reported [31]. Considering oleanolic acid, cochalic acid and chichipegenin, the presence of a carboxyl group at C-28 region of the oleananetype triterpenes might be effective for BACE1 inhibitory activity and the oleanane-type triterpenoid saponins might have less ability for inhibiting BACE1 activity.

In summary, six new saponins $(\mathbf{1 - 5 , 7})$ were isolated from Stenocereus pruinosus, and their structures were elucidated along with known saponins $(\mathbf{6 , 8 , 9})$. The structure of $\mathbf{1}$ has chichipegenin as the aglycone, in which C-3 and C-22 are glycosylated. Although saponins that have a sugar unit at C-22 to some extent have been identified [32-34], this is the first report in the case of chichipegenin. Compounds 2-3 and 4 have longispinogenin or erythrodiol as the aglycone moiety. Some saponins that have longispinogenin or erythrodiol as the aglycone have already been reported [35-42], but this is the first report of their isolation from cacti. Saponins $\mathbf{5}$ and 6-7 have cochalic acid or oleanolic acid as the aglycone. These types of saponin has been also isolated from another cactus, Polaskia chichipe [6], but the sugar unit differs from known ones. With respect to the sugar unit, 6 has a unique sugar chain for cactus plants. There are some reports related to that type of sugar chain [28,43-47], as it is not a common sugar unit, and this is the first report of its isolation from cacti. Paying attention to glucuronic acid, some compounds $(\mathbf{3}, \mathbf{4}, \mathbf{9})$ were isolated as glucuronic acid methyl esters. As compound $\mathbf{3}$ and $\mathbf{9}$ appeared to be derivatives of $\mathbf{2}$ and $\mathbf{8}$, compounds 3,4 and 9 could be artifacts caused by methanol extraction, which thought to be similar case to our previous report [5]. Some of the isolated saponins $(\mathbf{1 - 4 , 7 - 8})$ and hydrolysate of $\mathbf{8}(\mathbf{8 a})$ were tested for their ability to inhibit $\mathrm{A} \beta$ aggregation and BACE1 activity. Compound 7 was most effective at inhibiting $A \beta$ aggregation, followed by compounds 1 and 4. Oleanolic acid exhibited less of an effect on $\mathrm{A} \beta$ aggregation, as the structure consisting of oleanolic acid and sugar units is important for attenuating $A \beta$ aggregation. Results observed with compound 7 also suggested that glycosylations at C-28 of oleanolic acid is important for attenuating $\mathrm{A} \beta$ aggregation. In the BACE1 assay, tested compounds exhibited no inhibitory effect on BACE1 activity except for oleanolic acid and cochalic acid. Although six new saponins were described, more isolations from cacti should be pursued because of their unique structures, and additional SARs should be conducted to characterize the relationship to inhibition of $A \beta$ aggregation and BACE1 activity.

\section{Experimental}

\section{General experimental procedures}

Optical rotation values were recorded with a Horiba SEPA300 polarimeter. IR spectra were measured with a Thermo FT-IR Nicolet iS5 spectrometer (ATR). ${ }^{1} \mathrm{H}$ - and ${ }^{13} \mathrm{C}-\mathrm{NMR}$ spectra were recorded using a JNM LA-500 spectrometer. HRFABMS spectra were obtained using a JEOL JMS-700 spectrometer. Column chromatography was carried out with silica gel $60 \mathrm{~N}(63-210 \mu \mathrm{m})$ from Kanto Chemical, ODS silica gel YMC-GEL ODS-A from YMC Co. Ltd., and Diaion HP-20 from Mitsubishi Chemical Co. Ion-exchange chromatography was performed using Dowex $50 \mathrm{~W}-\mathrm{X} 8$ resin (50-100 mesh, H-form) from Sigma-Aldrich. Thinlayer chromatography was carried out using TLC silica gel $60 \mathrm{~F}_{254}$ and RP-18 $\mathrm{F}_{254 \mathrm{~S}}$ plates from Merck. Inhibition of $\mathrm{A} \beta$ aggregation was assayed using a Synergy HTX Multi-Mode Reader (BioTek, Winooski, Vermont, USA), A $\beta_{40}$ (Peptide Institute, Osaka, Japan), and thioflavin-T (Fujifilm-Wako).

\section{Plant material}

Stenocereus pruinosus (Otto) Buxb. was purchased from Hokoen (Iga City, Mie, Japan). A voucher specimen is deposited at our laboratory. 


\section{Extraction and isolation}

Aerial parts of $S$. pruinosus were dried, and the dry powder $(639.1 \mathrm{~g})$ was extracted three times with $\mathrm{CHCl}_{3}$ and then extracted three times with $\mathrm{MeOH}$. The $\mathrm{MeOH}$ extract (144.2 g) was applied to a Diaion HP-20 column, which was successively eluted with $\mathrm{MeOH}-\mathrm{H}_{2} \mathrm{O}$ mixture to give 4 fractions $\left[\mathrm{H}_{2} \mathrm{O}\right.$-eluted fraction (disposal), $30 \%$ $\mathrm{MeOH}-$ eluted fraction $(15.0 \mathrm{~g}), 70 \% \mathrm{MeOH}$-eluted fraction $(60.3 \mathrm{~g})$, and $100 \% \mathrm{MeOH}$-eluted fraction (106.5 g)], respectively.

The $70 \% \mathrm{MeOH}$-eluted fraction $(60.3 \mathrm{~g})$ was subjected to silica gel column chromatography (Si. C. C.) using a $\mathrm{CHCl}_{3}-\mathrm{MeOH}-\mathrm{H}_{2} \mathrm{O}$ mixture to give 10 fractions (A-J). Fr. H (10.3 g) was subjected to $\mathrm{Si}$. C. C. using a $\mathrm{CHCl}_{3}-\mathrm{MeOH}-\mathrm{H}_{2} \mathrm{O}$ mixture to give 3 fractions $(\mathrm{Ha}-\mathrm{Hc})$. Fr. $\mathrm{Hb}(7.5 \mathrm{~g})$ was subjected to $\mathrm{Si}$. C. C. using a $\mathrm{CHCl}_{3}-\mathrm{MeOH}-\mathrm{H}_{2} \mathrm{O}$ mixture to give 5 fractions (Hb1-Hb5). Fr. Hb4 (5.0 g) was subjected to Si. C. C. using a $\mathrm{CHCl}_{3}-\mathrm{MeOH}-\mathrm{H}_{2} \mathrm{O}$ mixture to give 3 fractions (Hb4-1-Hb4-3). Fr. Hb4-2 (4.1 g) was subjected to octadecyl-silylated silica gel column chromatography (ODS C. C.) using a $\mathrm{MeOH}-\mathrm{H}_{2} \mathrm{O}$ mixture to give 5 fractions (Hb4-2a-Hb4-2e). Fr. Hb4-2b (93.6 mg) was subjected to ODS C. C. using a $\mathrm{MeOH}-\mathrm{H}_{2} \mathrm{O}$ mixture to give 3 fractions (Hb4-2b-1-Hb4-2b-3). Fr. Hb4-2b-2 (48.3 mg) was further separated by $\mathrm{Si}$. C. C. using a $\mathrm{CHCl}_{3}-\mathrm{MeOH}-\mathrm{H}_{2} \mathrm{O}$ mixture to afford chichipenoside D (1, $16.7 \mathrm{mg}, 0.003 \%$, Fr. $\mathrm{Hb} 4-2 \mathrm{~b}-2 \mathrm{~d})$.

Fr. Hb4-2d (1.0 g) was subjected to ODS C. C. using a $\mathrm{MeOH}-\mathrm{H}_{2} \mathrm{O}$ mixture to give 3 fractions (Hb4-2d-1-Hb42d-3). Fr. Hb4-2d-2 (905.5 mg) was subjected to Si. C. C. using a $\mathrm{CHCl}_{3}-\mathrm{MeOH}-\mathrm{H}_{2} \mathrm{O}$ mixture to give 3 fractions (Hb4-2d-2a-Hb4-2d-2c). Fr. Hb4-2d-2b (202.3 mg) was further separated by ODS C. C. using a $\mathrm{MeCN}-\mathrm{H}_{2} \mathrm{O}$ mixture to afford oleanolic acid 3-O- $\beta$-D-xylopyranosyl- $(1 \rightarrow 2)-\alpha-\mathrm{L}-$ rhamnopyranosyl- $(1 \rightarrow 3)-\beta$ - D-glucuronopyranosyl-28-O- $\beta$ D-glucopyranoside (6, $72.0 \mathrm{mg}, 0.011 \%$, Fr. Hb4-2d-2b-9).

Fr. $\mathrm{Hb} 2(853.5 \mathrm{mg})$ was subjected to ODS C. C. using a $\mathrm{MeOH}-\mathrm{H}_{2} \mathrm{O}$ mixture to afford 5 fractions $(\mathrm{Hb} 2-1-\mathrm{Hb} 2-5)$ and oleanolic acid 3- $O-\alpha$-L-rhamnopyranosyl- $(1 \rightarrow 3)-\beta$-Dglucuronopyranosyl-28- $O$ - $\beta$-D-glucopyranoside (8, $440.3 \mathrm{mg}, 0.069 \%$, Fr. Hb2-4).

Fr. Hb2-2 (86.5 mg) was subjected to Si. C. C. using a $\mathrm{CHCl}_{3}-\mathrm{MeOH}-\mathrm{H}_{2} \mathrm{O}$ mixture to afford cochalinoside $\mathrm{C}(\mathbf{5}$, $27.5 \mathrm{mg}, 0.004 \%$, Fr. Hb2-2e).

The $100 \% \mathrm{MeOH}-$ eluted fraction $(94.5 \mathrm{~g})$ was subjected to Si. C. C. using a $\mathrm{CHCl}_{3}-\mathrm{MeOH}-\mathrm{H}_{2} \mathrm{O}$ mixture to give 8 fractions (1-8). Fr. $4(1.9 \mathrm{~g})$ was subjected to ODS C. C. using a $\mathrm{MeCN}-\mathrm{H}_{2} \mathrm{O}$ mixture to give 3 fractions $(4 \mathrm{~A}-4 \mathrm{C})$. Fr. 4B $(1.2 \mathrm{~g})$ was subjected to $\mathrm{Si}$. C. C. using a $\mathrm{CHCl}_{3}-\mathrm{MeOH}-\mathrm{H}_{2} \mathrm{O}$ mixture to afford oleanolic acid 3- $O$ - $\alpha$-L-rhamnopyranosyl- $(1 \rightarrow 3)-6^{\prime}-O$-methyl- $\beta$-D- glucuronopyranosyl-28- $O$ - $\beta$-D-glucopyranoside $(\mathbf{9}, 40.5 \mathrm{mg}$, $0.006 \%$, Fr. 4B-2).

Fr. 5 (15.9 g) was subjected to Si. C. C. using a $\mathrm{CHCl}_{3}-\mathrm{MeOH}-\mathrm{H}_{2} \mathrm{O}$ mixture to give 6 fractions $(5 \mathrm{~A}-5 \mathrm{~F})$. Fr. 5E (300.8 mg) was subjected to ODS C. C. using a $\mathrm{MeOH}-\mathrm{H}_{2} \mathrm{O}$ mixture to give 2 fractions (Fr. 5E-1-5E-2). Fr. $5 \mathrm{E}-1(235.2 \mathrm{mg})$ were partially $(46.0 \mathrm{mg})$ subjected to ODS C. C. using a $\mathrm{MeCN}-\mathrm{H}_{2} \mathrm{O}$ mixture to afford longispinoside A $(2,16.0 \mathrm{mg}, 0.003 \%$, Fr. 5E-1e).

Fr. 5B $(186.1 \mathrm{mg})$ was subjected to ODS C. C. using a $\mathrm{MeCN}-\mathrm{H}_{2} \mathrm{O}$ mixture to give 3 fractions (5B-1-5B-3). Fr. 5B-2 $(51.4 \mathrm{mg})$ was subjected to ODS C. C. using a $\mathrm{MeOH}-\mathrm{H}_{2} \mathrm{O}$ mixture to afford longispinoside A methyl ester (3, $24.2 \mathrm{mg}, 0.004 \%$, Fr. 5B-2c).

Fr. 5D (391.3 mg) was subjected to ODS C. C. using a $\mathrm{MeOH}-\mathrm{H}_{2} \mathrm{O}$ mixture to give 3 fractions (5D-1-5D-3). Fr. 5D-2 $(54.3 \mathrm{mg})$ was subjected to ODS C. C. using a $\mathrm{MeOH}-\mathrm{H}_{2} \mathrm{O}$ mixture to give 2 fractions (5D-2a-5D-2b). Fr. 5D-2b (40.3 mg) was subjected to ODS C. C. using a $\mathrm{MeCN}-\mathrm{H}_{2} \mathrm{O}$ mixture to afford erythronoside A methyl ester (4, $9.3 \mathrm{mg}, 0.001 \%$, Fr. 5D-2b-6).

Fr. 8 (6.1 g) was subjected to Si. C. C. using a $\mathrm{CHCl}_{3}-\mathrm{MeOH}-\mathrm{H}_{2} \mathrm{O}$ mixture to give 2 fractions (8A-8B). $\mathrm{Fr}$. $8 \mathrm{~B}(1.6 \mathrm{~g})$ was subjected to ODS C. C. using a $\mathrm{MeOH}-\mathrm{H}_{2} \mathrm{O}$ mixture to afford stenoside A (7, $28.9 \mathrm{mg}, 0.005 \%$, Fr. 8B-3).

Chichipenoside D (1): colorless amorphous powder; $[\alpha]_{D}^{21}-28.0(c 0.25, \mathrm{MeOH})$; IR (ATR) $\nu_{\max }: 3385,2939$, $1714,1602,1417,1376,1293,1041 \mathrm{~cm}^{-1} ;{ }^{1} \mathrm{H}-$ and ${ }^{13} \mathrm{C}-$ NMR (DMSO- $d_{6}, 500$ and $125 \mathrm{MHz}$ ), see Tables 2 and 3; negative HRFABMS $m / z: 1103.5640[\mathrm{M}-\mathrm{H}]^{-}$(calcd for $\mathrm{C}_{54} \mathrm{H}_{87} \mathrm{O}_{23}, 1103.5640$ ).

Longispinoside A (2): colorless amorphous powder, $[\alpha]_{D^{-}}^{18}-0$ (c 0.2 MeOH); IR (ATR) $\nu_{\max }: 3330,2940,1740$, 1450, $1020 \mathrm{~cm}^{-1}$; ${ }^{1} \mathrm{H}$ - and ${ }^{13} \mathrm{C}-\mathrm{NMR}$ (DMSO- $d_{6}, 500$ and $125 \mathrm{MHz}$ ), see Tables 2 and 3; positive HRFABMS $\mathrm{m} / \mathrm{z}$ : $803.4546[\mathrm{M}+\mathrm{Na}]^{+}$(calcd for $\left.\mathrm{C}_{42} \mathrm{H}_{68} \mathrm{O}_{13} \mathrm{Na}, 803.4548\right)$.

Longispinoside A methyl ester (3): colorless amorphous powder, $[\alpha]^{19}{ }_{\mathrm{D}}-117.3(c 0.1 \mathrm{MeOH})$; IR (ATR) $\nu_{\max }$ : 3363, 2945, 1746, 1442, $1024 \mathrm{~cm}^{-1} ;{ }^{1} \mathrm{H}-$ and ${ }^{13} \mathrm{C}-\mathrm{NMR}$ (DMSO- $d_{6}, 500$ and $125 \mathrm{MHz}$ ), see Tables 2 and 3; positive HRFABMS $m / z: 795.4900[\mathrm{M}+\mathrm{H}]^{+}\left(\right.$calcd for $\mathrm{C}_{43} \mathrm{H}_{71} \mathrm{O}_{13}$, 795.4895).

Erythronoside A methyl ester (4): colorless amorphous powder, $[\alpha]^{19} \mathrm{D}^{-4.1}($ c $0.1 \mathrm{MeOH})$; IR (ATR) $\nu_{\max }: 3330$, 2970, $1752,1040 \mathrm{~cm}^{-1} ;{ }^{1} \mathrm{H}$ - and ${ }^{13} \mathrm{C}-\mathrm{NMR}$ (DMSO- $d_{6}, 500$ and $125 \mathrm{MHz}$ ), see Tables 2 and 3; positive HRFABMS $m / z$ : $941.5481[\mathrm{M}+\mathrm{H}]^{+}\left(\right.$calcd for $\left.\mathrm{C}_{43} \mathrm{H}_{71} \mathrm{O}_{13}, 941.5474\right)$.

Cochalinoside $\mathrm{C}(\mathbf{5})$ : colorless amorphous powder, $[\alpha]^{22}{ }_{\mathrm{D}}-28.8$ (c $\left.0.25 \mathrm{MeOH}\right)$; IR (ATR) $\nu_{\max }: 3370,2970$, $2940,1710,1610,1420,1390,1240,1140,1050 \mathrm{~cm}^{-1},{ }^{1} \mathrm{H}-$ and ${ }^{13} \mathrm{C}$-NMR (DMSO- $d_{6}, 500$ and $125 \mathrm{MHz}$ ), see Tables 2 and 3; negative HRFABMS m/z: $939.4952[\mathrm{M}-\mathrm{H}]^{-}$(calcd for $\mathrm{C}_{48} \mathrm{H}_{75} \mathrm{O}_{18}$, 939.4962). 


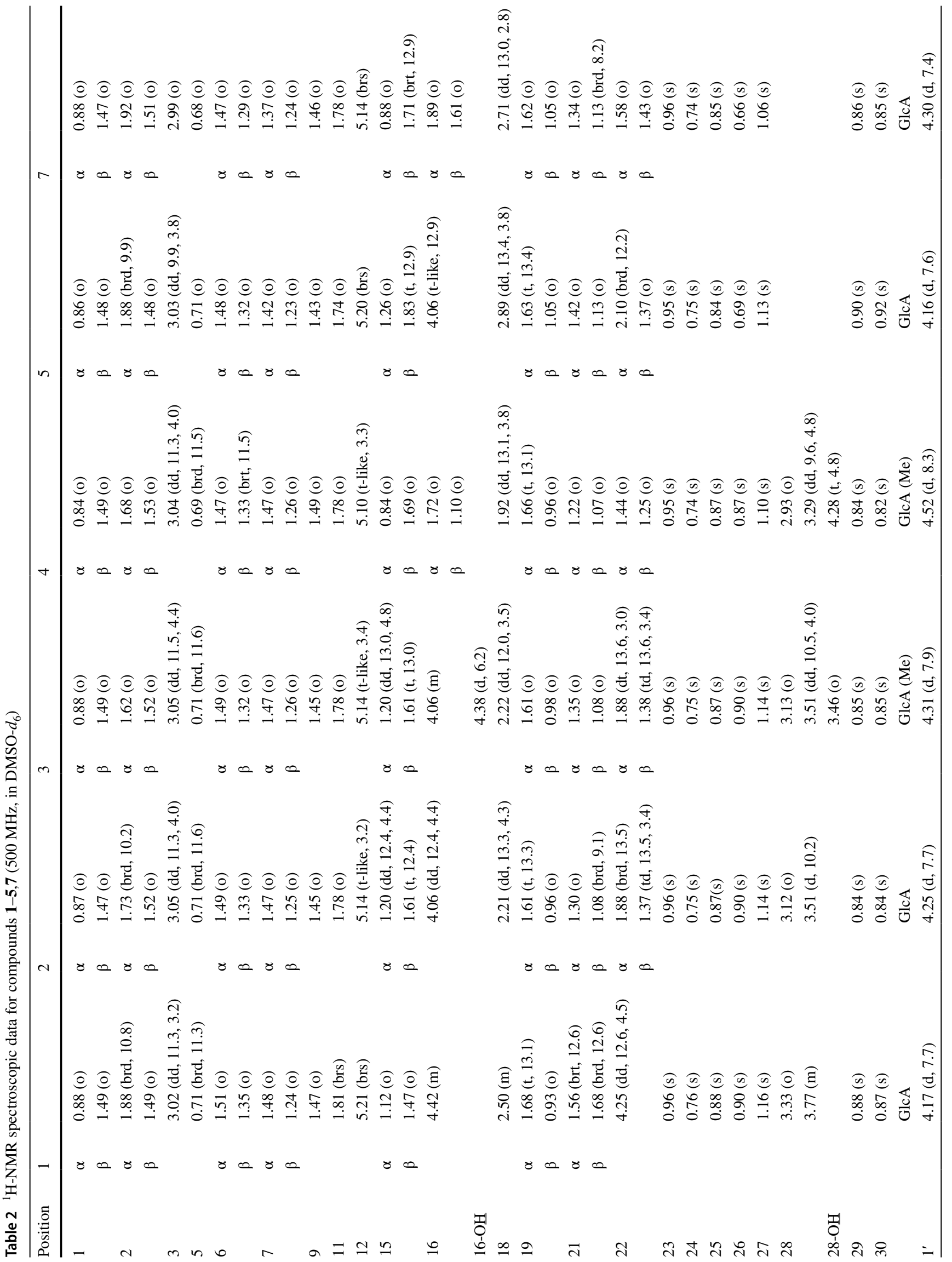




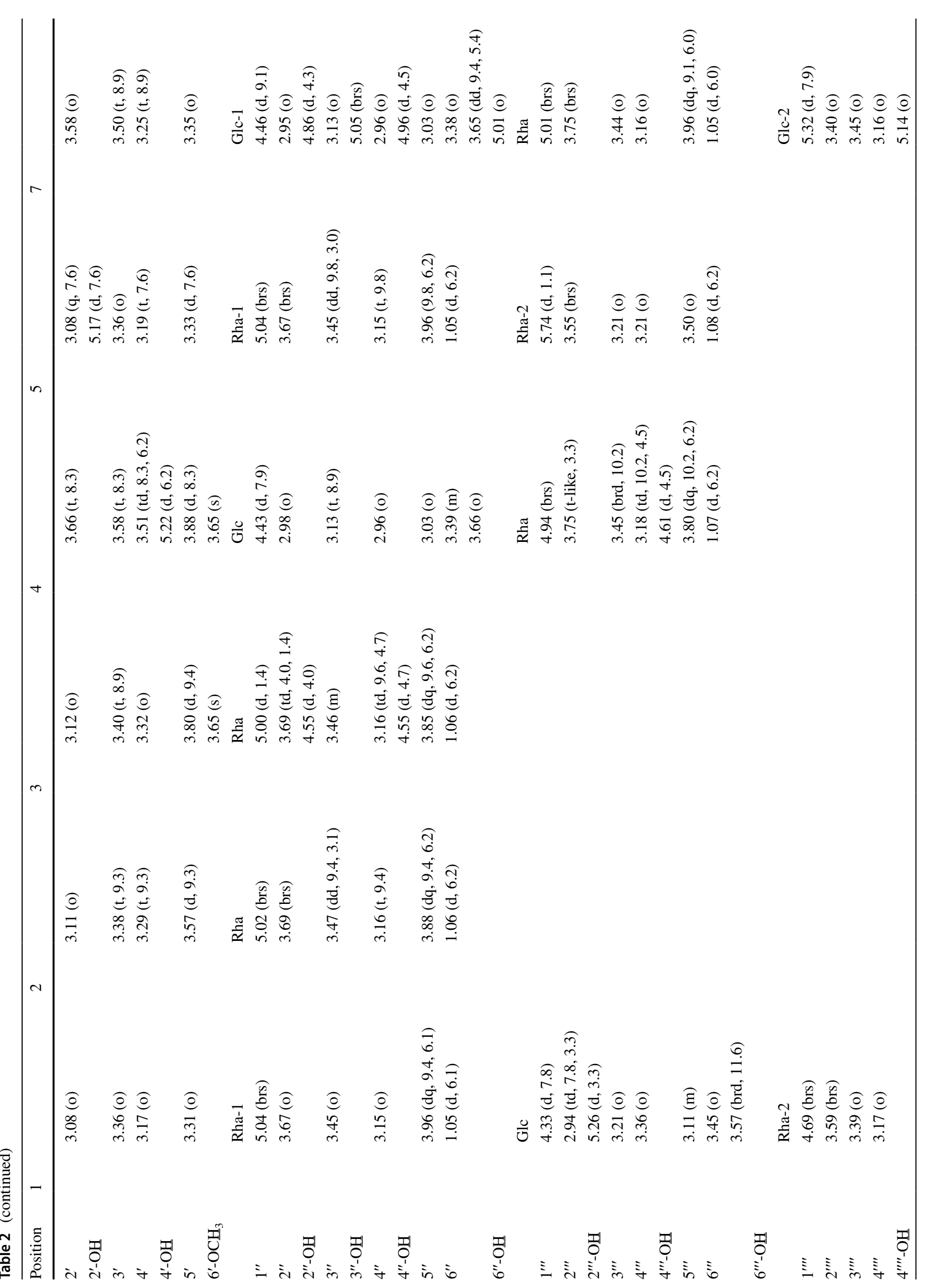




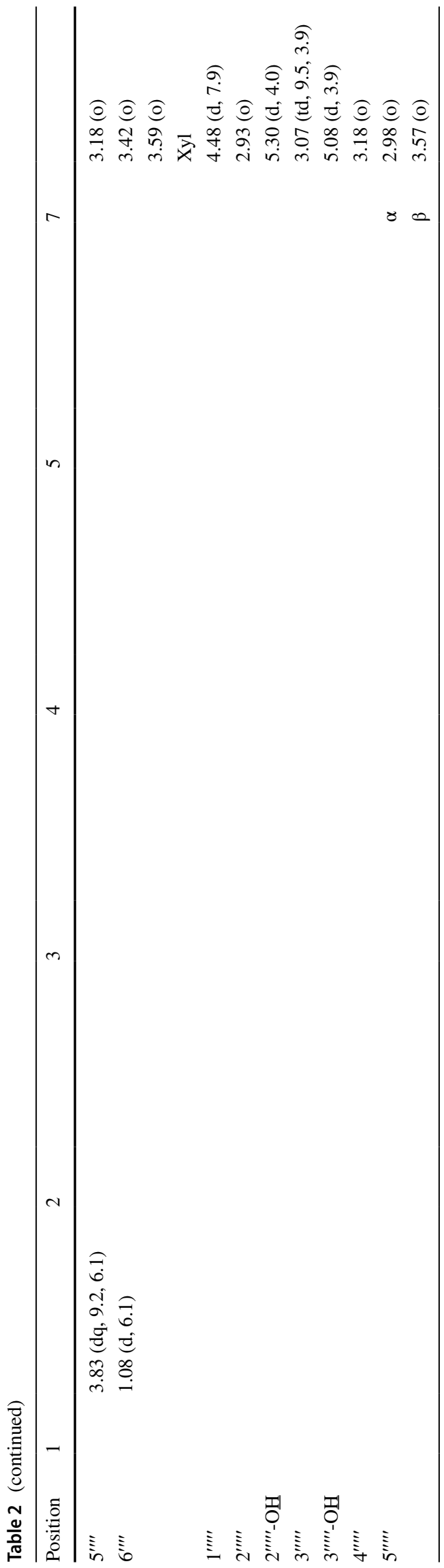

Oleanolic acid 3-O- $\beta$-D-xylopyranosyl- $(1 \rightarrow 2)-\alpha-\mathrm{L}-$ rhamnopyranosyl- $(1 \rightarrow 3)-\beta$-D-glucuronopyranosyl-28-O- $\beta$ D-glucopyranoside (6): colorless amorphous powder, $[\alpha]^{23}{ }_{D}$ -4.9 ( с 0.3 MeOH); IR (ATR) $\nu_{\max }: 3370,2970,2930,1730$, 1460, 1390, 1260, 1230, $1020 \mathrm{~cm}^{-1} ;{ }^{1} \mathrm{H}-$ and ${ }^{13} \mathrm{C}-\mathrm{NMR}$ (DMSO- $d_{6}, 500$ and $125 \mathrm{MHz}$ ), see Tables 2 and 3; negative HRFABMS m/z: $1071.5386[\mathrm{M}-\mathrm{H}]^{-}{ }^{-}$calcd for $\mathrm{C}_{53} \mathrm{H}_{83} \mathrm{O}_{22}$, 1071.5309).

Stenoside A (7): colorless amorphous powder, $[\alpha]^{19}{ }_{D}$ -8.6 (c $0.1 \mathrm{MeOH}$ ); IR (ATR) $\nu_{\text {max }}: 3372,2927,1732$, 1602, 1417, 1260, 1074, $1041 \mathrm{~cm}^{-1} ;{ }^{1} \mathrm{H}-$ and ${ }^{13} \mathrm{C}-\mathrm{NMR}$ (DMSO- $d_{6}, 500$ and $125 \mathrm{MHz}$ ), see Tables 2 and 3; positive HRFABMS $m / z: 1273.5642979 .4658[\mathrm{M}+\mathrm{K}]^{+}$(calcd for $\left.\mathrm{C}_{59} \mathrm{H}_{94} \mathrm{O}_{27} \mathrm{~K}, 1273.5620\right)$.

\section{Alkaline hydrolysis of 8}

Oleanolic acid 3- $O$ - $\alpha$-L-rhamnopyranosyl-( $1 \rightarrow 3)-\beta$-Dglucuronopyranosyl-28-O- $\beta$-D-glucopyranoside (8) $(10.1 \mathrm{mg})$ was dissolved in $4 \mathrm{~mL}$ of $\mathrm{MeOH}$ and hydrolyzed with $0.4 \mathrm{~mL}$ of $5 \% \mathrm{~K}_{2} \mathrm{CO}_{3}$ aq. solution under reflux for $4 \mathrm{~h}$ at $110{ }^{\circ} \mathrm{C}$. After the reaction, the mixture was subjected to DOWEX $50 \mathrm{~W}-\mathrm{X} 8$ to remove potassium ions. After washing with plenty of $\mathrm{MeOH}$, the eluent was evaporated to dryness. The residue was chromatographed over ODS C. C. using a stepwise gradient $(80 \% \mathrm{MeOH} \rightarrow 100 \% \mathrm{MeOH})$ to afford hydrolysate $(\mathbf{8 a})(2.0 \mathrm{mg})$, the $28-O$-deglycosylated saponin of 8 .

\section{Determination of sugar configuration}

Sugar configuration was determined according to a previously reported procedure [25]. Saponins (1-7) (each $2 \mathrm{mg}$ ) were dissolved in $1 \mathrm{M} \mathrm{HCl}(0.4 \mathrm{~mL})$ and then heated at $110{ }^{\circ} \mathrm{C}$ for $2 \mathrm{~h}$. Following neutralization with $1 \mathrm{M} \mathrm{NaOH}$, the reaction mixture was evaporated under reduced pressure to dryness, and then the residue was dissolved in pyridine $(0.4 \mathrm{~mL})$ containing L-cysteine methyl ester hydrochloride $(2 \mathrm{mg})$ and heated at $60{ }^{\circ} \mathrm{C}$ for $1 \mathrm{~h}$. $O$-Tolylisothiocyanate $(2 \mu \mathrm{L})$ was then added to the mixture, and it was heated at $60{ }^{\circ} \mathrm{C}$ for $1 \mathrm{~h}$. The reaction mixture was analyzed by HPLC using a system equipped with a PU-2089 pump, UV-2075 UV/VIS detector (Nippon Bunko Co.), and Senshu Pak PEGASIL 4.6 $\phi \times 250$ mm HPLC column (temp, $35{ }^{\circ} \mathrm{C}$; flow, $0.8 \mathrm{~mL} / \mathrm{min}$; elution buffer, $\mathrm{MeCN}-\mathrm{H}_{2} \mathrm{O} 25: 75$ containing $50 \mathrm{mM} \mathrm{H}_{3} \mathrm{PO}_{4}$ ). The HPLC column was washed with $\mathrm{MeOH}$ after each injection. The reaction conditions for $\mathrm{D}, \mathrm{L}-$ glucose, D-glucuronic acid, D, L-xylose, and L-rhamnose were the same as described above except for the mass, authentic sugar $(5 \mathrm{mg})$, and L-cysteine methyl ester hydrochloride (5 mg), respectively. L-Glucuronic acid and D-rhamnose derivatives were synthesized from D-glucuronic acid, 
Table $3{ }^{13} \mathrm{C}$-NMR

spectroscopic data for compounds $\mathbf{1 - 5 , 7}(125 \mathrm{MHz}$ in DMSO- $d_{6}$ )

\begin{tabular}{|c|c|c|c|c|c|c|c|c|c|c|c|c|}
\hline Position & 1 & & 2 & & 3 & & 4 & & 5 & & 7 & \\
\hline 1 & 38.3 & $\mathrm{CH}_{2}$ & 38.2 & $\mathrm{CH}_{2}$ & 38.1 & $\mathrm{CH}_{2}$ & 38.1 & $\mathrm{CH}_{2}$ & 38.2 & $\mathrm{CH}_{2}$ & 38.3 & $\mathrm{CH}_{2}$ \\
\hline 2 & 25.4 & $\mathrm{CH}_{2}$ & 25.6 & $\mathrm{CH}_{2}$ & 25.6 & $\mathrm{CH}_{2}$ & 25.4 & $\mathrm{CH}_{2}$ & 25.4 & $\mathrm{CH}_{2}$ & 25.4 & $\mathrm{CH}_{2}$ \\
\hline 3 & 88.1 & $\mathrm{CH}$ & 88.3 & $\mathrm{CH}$ & 88.4 & $\mathrm{CH}$ & 88.6 & $\mathrm{CH}$ & 88.1 & $\mathrm{CH}$ & 88.7 & $\mathrm{CH}$ \\
\hline 4 & 38.7 & $\mathrm{C}$ & 38.7 & $\mathrm{C}$ & 38.7 & $\mathrm{C}$ & 38.6 & $\mathrm{C}$ & 38.7 & $\mathrm{C}$ & 38.7 & $\mathrm{C}$ \\
\hline 5 & 54.8 & $\mathrm{C}$ & 54.8 & $\mathrm{CH}$ & 54.8 & $\mathrm{CH}$ & 54.8 & $\mathrm{CH}$ & 55.0 & $\mathrm{CH}$ & 55.2 & $\mathrm{CH}$ \\
\hline 6 & 17.7 & $\mathrm{CH}_{2}$ & 17.8 & $\mathrm{CH}_{2}$ & 17.7 & $\mathrm{CH}_{2}$ & 17.8 & $\mathrm{CH}_{2}$ & 17.7 & $\mathrm{CH}_{2}$ & 17.9 & $\mathrm{CH}_{2}$ \\
\hline 7 & 32.1 & $\mathrm{CH}_{2}$ & 32.2 & $\mathrm{CH}_{2}$ & 32.1 & $\mathrm{CH}_{2}$ & 32.1 & $\mathrm{CH}_{2}$ & 32.4 & $\mathrm{CH}_{2}$ & 32.3 & $\mathrm{CH}_{2}$ \\
\hline 8 & 39.4 & $\mathrm{C}$ & 39.2 & $\mathrm{C}$ & 39.1 & $\mathrm{C}$ & 39.9 & $\mathrm{C}$ & 39.2 & $\mathrm{C}$ & 39.1 & $\mathrm{C}$ \\
\hline 9 & 46.2 & $\mathrm{CH}$ & 46.2 & $\mathrm{CH}$ & 46.2 & $\mathrm{CH}$ & 47.0 & $\mathrm{CH}$ & 46.2 & $\mathrm{CH}$ & 47.1 & $\mathrm{CH}$ \\
\hline 10 & 36.1 & $\mathrm{C}$ & 36.1 & $\mathrm{C}$ & 36.1 & $\mathrm{C}$ & 36.1 & $\mathrm{C}$ & 36.2 & $\mathrm{C}$ & 36.3 & $\mathrm{C}$ \\
\hline 11 & 23.1 & $\mathrm{CH}_{2}$ & 23.0 & $\mathrm{CH}_{2}$ & 23.0 & $\mathrm{CH}_{2}$ & 23.0 & $\mathrm{CH}_{2}$ & 23.0 & $\mathrm{CH}_{2}$ & 23.0 & $\mathrm{CH}_{2}$ \\
\hline 12 & 122.4 & $\mathrm{CH}$ & 121.4 & $\mathrm{CH}$ & 121.6 & $\mathrm{CH}$ & 121.5 & $\mathrm{CH}$ & 122.2 & $\mathrm{CH}$ & 121.7 & $\mathrm{CH}$ \\
\hline 13 & 141.9 & $\mathrm{C}$ & 143.3 & $\mathrm{C}$ & 143.3 & $\mathrm{C}$ & 144.3 & $\mathrm{C}$ & 142.4 & $\mathrm{C}$ & 143.5 & $\mathrm{C}$ \\
\hline 14 & 41.7 & $\mathrm{C}$ & 42.9 & $\mathrm{C}$ & 42.9 & $\mathrm{C}$ & 41.2 & $\mathrm{C}$ & 43.3 & $\mathrm{C}$ & 41.2 & $\mathrm{C}$ \\
\hline 15 & 34.8 & $\mathrm{CH}_{2}$ & 35.2 & $\mathrm{CH}_{2}$ & 35.2 & $\mathrm{CH}_{2}$ & 25.1 & $\mathrm{CH}_{2}$ & 36.5 & $\mathrm{CH}_{2}$ & 27.6 & $\mathrm{CH}_{2}$ \\
\hline 16 & 64.5 & $\mathrm{CH}$ & 64.5 & $\mathrm{CH}$ & 64.5 & $\mathrm{CH}$ & 21.7 & $\mathrm{CH}_{2}$ & 62.7 & $\mathrm{CH}$ & 22.1 & $\mathrm{CH}_{2}$ \\
\hline 17 & 44.6 & $\mathrm{C}$ & 40.1 & $\mathrm{C}$ & 40.1 & $\mathrm{C}$ & 36.5 & $\mathrm{C}$ & 50.1 & $\mathrm{C}$ & 46.0 & $\mathrm{C}$ \\
\hline 18 & 42.0 & $\mathrm{CH}$ & 42.6 & $\mathrm{CH}$ & 42.6 & $\mathrm{CH}$ & 41.8 & $\mathrm{CH}$ & 43.3 & $\mathrm{CH}$ & 40.8 & $\mathrm{CH}$ \\
\hline 19 & 45.5 & $\mathrm{CH}_{2}$ & 46.4 & $\mathrm{CH}_{2}$ & 46.3 & $\mathrm{CH}_{2}$ & 46.3 & $\mathrm{CH}_{2}$ & 45.1 & $\mathrm{CH}_{2}$ & 45.5 & $\mathrm{CH}_{2}$ \\
\hline 20 & 31.4 & $\mathrm{C}$ & 30.5 & $\mathrm{C}$ & 30.5 & $\mathrm{C}$ & 30.7 & $\mathrm{C}$ & 30.2 & $\mathrm{C}$ & 30.3 & $\mathrm{C}$ \\
\hline 21 & 41.0 & $\mathrm{CH}_{2}$ & 33.5 & $\mathrm{CH}_{2}$ & 33.5 & $\mathrm{CH}_{2}$ & 33.8 & $\mathrm{CH}_{2}$ & 32.4 & $\mathrm{CH}_{2}$ & 33.3 & $\mathrm{CH}_{2}$ \\
\hline 22 & 77.9 & $\mathrm{CH}$ & 23.8 & $\mathrm{CH}_{2}$ & 23.8 & $\mathrm{CH}_{2}$ & 30.9 & $\mathrm{CH}_{2}$ & 25.9 & $\mathrm{CH}_{2}$ & 31.5 & $\mathrm{CH}_{2}$ \\
\hline 23 & 27.6 & $\mathrm{CH}_{3}$ & 27.5 & $\mathrm{CH}_{3}$ & 27.4 & $\mathrm{CH}_{3}$ & 27.5 & $\mathrm{CH}_{3}$ & 27.5 & $\mathrm{CH}_{3}$ & 27.6 & $\mathrm{CH}_{3}$ \\
\hline 24 & 16.4 & $\mathrm{CH}_{3}$ & 16.3 & $\mathrm{CH}_{3}$ & 16.3 & $\mathrm{CH}_{3}$ & 16.1 & $\mathrm{CH}_{3}$ & 16.4 & $\mathrm{CH}_{3}$ & 16.2 & $\mathrm{CH}_{3}$ \\
\hline 25 & 15.3 & $\mathrm{CH}_{3}$ & 15.3 & $\mathrm{CH}_{3}$ & 15.3 & $\mathrm{CH}_{3}$ & 15.3 & $\mathrm{CH}_{3}$ & 15.1 & $\mathrm{CH}_{3}$ & 15.2 & $\mathrm{CH}_{3}$ \\
\hline 26 & 16.6 & $\mathrm{CH}_{3}$ & 16.5 & $\mathrm{CH}_{3}$ & 16.5 & $\mathrm{CH}_{3}$ & 16.4 & $\mathrm{CH}_{3}$ & 16.8 & $\mathrm{CH}_{3}$ & 16.7 & $\mathrm{CH}_{3}$ \\
\hline 27 & 26.8 & $\mathrm{CH}_{3}$ & 26.6 & $\mathrm{CH}_{3}$ & 26.6 & $\mathrm{CH}_{3}$ & 25.6 & $\mathrm{CH}_{3}$ & 26.7 & $\mathrm{CH}_{3}$ & 25.6 & $\mathrm{CH}_{3}$ \\
\hline 28 & 56.7 & $\mathrm{CH}_{2}$ & 65.2 & $\mathrm{CH}_{2}$ & 65.0 & $\mathrm{CH}_{2}$ & 67.4 & $\mathrm{CH}_{2}$ & 174.5 & $\mathrm{C}$ & 175.3 & $\mathrm{C}$ \\
\hline 29 & 32.8 & $\mathrm{CH}_{3}$ & 33.1 & $\mathrm{CH}_{3}$ & 33.1 & $\mathrm{CH}_{3}$ & 33.1 & $\mathrm{CH}_{3}$ & 32.7 & $\mathrm{CH}_{3}$ & 32.8 & $\mathrm{CH}_{3}$ \\
\hline 30 & 24.4 & $\mathrm{CH}_{3}$ & 23.7 & $\mathrm{CH}_{3}$ & 23.7 & $\mathrm{CH}_{3}$ & 23.5 & $\mathrm{CH}_{3}$ & 23.7 & $\mathrm{CH}_{3}$ & 23.4 & $\mathrm{CH}_{3}$ \\
\hline & GlcA & & GlcA & & GlcA (Me) & & GlcA (Me) & & GlcA & & GlcA & \\
\hline $1^{\prime}$ & 105.1 & $\mathrm{CH}$ & 105.2 & $\mathrm{CH}$ & 105.2 & $\mathrm{CH}$ & 103.1 & $\mathrm{CH}$ & 105.2 & $\mathrm{CH}$ & 103.6 & $\mathrm{CH}$ \\
\hline $2^{\prime}$ & 74.6 & $\mathrm{CH}$ & 74.3 & $\mathrm{CH}$ & 74.2 & $\mathrm{CH}$ & 77.0 & $\mathrm{CH}$ & 74.5 & $\mathrm{CH}$ & 77.7 & $\mathrm{CH}$ \\
\hline $3^{\prime}$ & 80.3 & $\mathrm{CH}$ & 80.4 & $\mathrm{CH}$ & 80.1 & $\mathrm{CH}$ & 81.1 & $\mathrm{CH}$ & 80.3 & $\mathrm{CH}$ & 81.6 & $\mathrm{CH}$ \\
\hline $4^{\prime}$ & 70.6 & $\mathrm{CH}$ & 70.2 & $\mathrm{CH}$ & 70.1 & $\mathrm{CH}$ & 69.9 & $\mathrm{CH}$ & 70.3 & $\mathrm{CH}$ & 70.9 & $\mathrm{CH}$ \\
\hline $5^{\prime}$ & 74.2 & $\mathrm{CH}$ & 75.1 & $\mathrm{CH}$ & 75.2 & $\mathrm{CH}$ & 74.8 & $\mathrm{CH}$ & 74.1 & $\mathrm{CH}$ & 74.0 & $\mathrm{CH}$ \\
\hline $6^{\prime}$ & 173.1 & $\mathrm{C}$ & 171.3 & $\mathrm{C}$ & 169.5 & $\mathrm{C}$ & 169.5 & $\mathrm{C}$ & 173.5 & $\mathrm{C}$ & 173.7 & $\mathrm{C}$ \\
\hline \multirow[t]{2}{*}{$6^{\prime}-\mathrm{OCH}_{3}$} & & & & & 51.9 & $\mathrm{CH}_{3}$ & 51.9 & $\mathrm{CH}_{3}$ & & & & \\
\hline & Rha-1 & & Rha & & Rha & & Glc & & Rha-1 & & Glc-1 & \\
\hline $1^{\prime \prime}$ & 100.2 & $\mathrm{CH}$ & 100.5 & $\mathrm{CH}$ & 100.7 & $\mathrm{CH}$ & 101.6 & $\mathrm{CH}$ & 100.3 & $\mathrm{CH}$ & 101.6 & $\mathrm{CH}$ \\
\hline $2^{\prime \prime}$ & 70.6 & $\mathrm{CH}$ & 70.6 & $\mathrm{CH}$ & 70.5 & $\mathrm{CH}$ & 70.4 & $\mathrm{CH}$ & $70.6^{*}$ & $\mathrm{CH}$ & 70.4 & $\mathrm{CH}$ \\
\hline $3^{\prime \prime}$ & 70.7 & $\mathrm{CH}$ & 70.6 & $\mathrm{CH}$ & 70.5 & $\mathrm{CH}$ & 76.6 & $\mathrm{CH}$ & 70.6 & $\mathrm{CH}$ & 76.6 & $\mathrm{CH}$ \\
\hline $4^{\prime \prime}$ & 72.1 & $\mathrm{CH}$ & 72.1 & $\mathrm{CH}$ & 72.0 & $\mathrm{CH}$ & 74.2 & $\mathrm{CH}$ & 72.1 & $\mathrm{CH}$ & 74.6 & $\mathrm{CH}$ \\
\hline $5^{\prime \prime}$ & 67.8 & $\mathrm{CH}$ & 68.0 & $\mathrm{CH}$ & 68.1 & $\mathrm{CH}$ & 77.0 & $\mathrm{CH}$ & 67.8 & $\mathrm{CH}$ & 77.0 & $\mathrm{CH}$ \\
\hline \multirow[t]{2}{*}{$6^{\prime \prime}$} & 17.9 & $\mathrm{CH}_{3}$ & 17.9 & $\mathrm{CH}_{3}$ & 17.8 & $\mathrm{CH}_{3}$ & 61.4 & $\mathrm{CH}_{2}$ & 17.9 & $\mathrm{CH}_{3}$ & 61.4 & $\mathrm{CH}_{2}$ \\
\hline & Glc & & & & & & Rha & & Rha-2 & & Rha & \\
\hline $1^{\prime \prime \prime}$ & 103.3 & $\mathrm{CH}$ & & & & & 100.5 & $\mathrm{CH}$ & 93.3 & $\mathrm{CH}$ & 100.6 & $\mathrm{CH}$ \\
\hline $2^{\prime \prime \prime}$ & 74.1 & $\mathrm{CH}$ & & & & & 70.6 & $\mathrm{CH}$ & 69.6 & $\mathrm{CH}$ & 70.6 & $\mathrm{CH}$ \\
\hline $3^{\prime \prime \prime}$ & 75.3 & $\mathrm{CH}$ & & & & & 70.6 & $\mathrm{CH}$ & 71.5 & $\mathrm{CH}$ & 70.8 & $\mathrm{CH}$ \\
\hline $4^{\prime \prime \prime}$ & 76.6 & $\mathrm{CH}$ & & & & & 71.9 & $\mathrm{CH}$ & 71.3 & $\mathrm{CH}$ & 72.1 & $\mathrm{CH}$ \\
\hline $5^{\prime \prime \prime}$ & 75.5 & $\mathrm{CH}$ & & & & & 68.6 & $\mathrm{CH}$ & 70.7 & $\mathrm{CH}$ & 68.2 & $\mathrm{CH}$ \\
\hline
\end{tabular}


Table 3 (continued)

\begin{tabular}{|c|c|c|c|c|c|c|c|c|c|}
\hline Position & 1 & 2 & 3 & 4 & & 5 & & 7 & \\
\hline $6^{\prime \prime \prime}$ & $\begin{array}{l}60.1 \\
\text { Rha-2 }\end{array}$ & $\mathrm{CH}_{2}$ & & 17.8 & $\mathrm{CH}_{3}$ & 17.9 & $\mathrm{CH}_{3}$ & $\begin{array}{l}17.9 \\
\text { Glc-2 }\end{array}$ & $\mathrm{CH}_{3}$ \\
\hline $1^{\prime \prime \prime \prime \prime}$ & 100.5 & $\mathrm{CH}$ & & & & & & 91.9 & $\mathrm{CH}$ \\
\hline $2^{\prime \prime \prime \prime}$ & 70.7 & $\mathrm{CH}$ & & & & & & 78.8 & $\mathrm{CH}$ \\
\hline $3^{\prime \prime \prime \prime}$ & 70.6 & $\mathrm{CH}$ & & & & & & 76.9 & $\mathrm{CH}$ \\
\hline $4^{\prime \prime \prime \prime}$ & 71.9 & $\mathrm{CH}$ & & & & & & 77.6 & $\mathrm{CH}$ \\
\hline $5^{\prime \prime \prime \prime}$ & 68.6 & $\mathrm{CH}$ & & & & & & 69.2 & $\mathrm{CH}$ \\
\hline $6^{\prime \prime \prime \prime}$ & 17.7 & $\mathrm{CH}_{3}$ & & & & & & $\begin{array}{l}60.6 \\
\text { Xyl }\end{array}$ & $\mathrm{CH}_{2}$ \\
\hline $1^{\prime \prime \prime \prime}$ & & & & & & & & 104.0 & $\mathrm{CH}$ \\
\hline $2^{\prime \prime \prime \prime}$ & & & & & & & & 74.2 & $\mathrm{CH}$ \\
\hline $3^{\prime \prime \prime \prime}$ & & & & & & & & 76.5 & $\mathrm{CH}$ \\
\hline $4^{\prime \prime \prime \prime}$ & & & & & & & & 69.5 & $\mathrm{CH}$ \\
\hline $5^{\prime \prime \prime \prime}$ & & & & & & & & 65.8 & $\mathrm{CH}_{2}$ \\
\hline
\end{tabular}

L-rhamnose (each $5 \mathrm{mg}$ ), and D-cysteine methyl ester hydrochloride $(5 \mathrm{mg})$. These derivatives were used for determining the retention time. The retention times (min.) for the authentic sugar derivatives were D-glucose (23.56), L-glucose (21.89), D-glucuronic acid (24.37), L-glucuronic acid (derived from D-glucuronic acid and D-cysteine methyl ester, 23.38), D-rhamnose (derived from L-rhamnose and D-cysteine methylester, 18.36), L-rhamnose (40.19), D-xylose (22.17), and L-xylose (20.14). These retention times were compared with the retention times of each saponin (1-7) in the reaction mixtures. The peaks at $23.55,24.25$, and $40.18 \mathrm{~min}$ of the sugar derivatives from 1 coincided with the derivatives of D-glucose, D-glucuronic acid, and L-rhamnose, respectively. The other saponins (2-7) provided the same results as $\mathbf{1}$.

\section{Th-T assay}

The rate of $A \beta$ aggregation was evaluated using a slightly modified thioflavin-T (Th-T) method described in a previous report [6]. The Th-T method was originally developed by Naiki and co-workers [48]. The rate of $A \beta$ aggregation was calculated by comparing the fluorescence intensity of each sample with that of a control $\left(25 \mu \mathrm{M}\right.$ of $\mathrm{A} \beta_{40}$ and DMSO containing no test sample). The aggregation rate $(\%)$ was calculated using the following formula: $[(S-B) /(C-B) \times 100]$, (S, fluorescence of Th-T solution incubated with $A \beta_{40}$ and sample; $C$, fluorescence of Th-T solution incubated with $\mathrm{A} \beta_{40}$ and DMSO; $\mathrm{B}$, fluorescence of Th-T solution not incubated with $\mathrm{A} \beta_{40}$ and DMSO). Myricetin (Fujifilm-Wako) was used as a positive control at $25 \mu \mathrm{M}$ as the final concentration, and that of test samples $(\mathbf{1 - 4 , 7 - 8})$ was $100 \mu \mathrm{M}$.

\section{BACE1 FRET assay}

BACE1 assays were performed in 384-well black plates using a BACE1 FRET assay kit, Red (Thermo Fisher Scientific, USA). The assay was carried out according to the supplied manual, with some modifications. Samples were dissolved in the assay buffer $(50 \mathrm{mM}$ sodium acetate, $\mathrm{pH} 4.5$ ) with DMSO (final concentrations were $10 \%$ ). Next, $9 \mu \mathrm{L}$ of test sample, $9 \mu \mathrm{L}$ of BACE1 substrate $(750 \mathrm{nM}$ Rh-EVNLDAEFK-Quencher, in $50 \mathrm{mM}$ ammonium bicarbonate), and $9 \mu \mathrm{L}$ of BACE1 enzyme $(1.0 \mathrm{U} / \mathrm{mL})$ were mixed in the wells and incubated $60 \mathrm{~min}$ in the dark at room temperature. The fluorescence intensity of each well was measured using a SYNERGY HTX multimode reader (BioTek, USA), with excitation at $540 \mathrm{~nm}$ and emission at $590 \mathrm{~nm}$. The inhibition ratio was calculated by the following formula: Inhibition rate $(\%)=\left\{1-\left[\left(S-S_{0}\right)-\left(B-B_{0}\right)\right] /\left[\left(C-C_{0}\right)-\left(B-B_{0}\right)\right]\right\} \times 100$, where $C$ represents the fluorescence of a control [enzyme, substrate, and assay buffer concentration with DMSO (final concentrations 10\%)] after 60 min of incubation, $\mathrm{C}_{0}$ represents the initial fluorescence of a control [enzyme, substrate, and assay buffer concentration with DMSO (final concentrations 10\%)], B represents the fluorescence of a control [substrate and assay buffer concentration with DMSO (final concentrations 10\%)] after $60 \mathrm{~min}$ of incubation, $\mathrm{B}_{0}$ represents the initial fluorescence of a control [substrate and assay buffer concentration with DMSO (final concentrations were 10\%)], S represents the fluorescence of the tested sample (enzyme, sample solution, and substrate) after 60 min of incubation, and $\mathrm{S}_{0}$ represents the initial fluorescence of the tested sample (enzyme, sample solution, and substrate). $\beta$-Secretase inhibitor IV (Merck, Germany) was used as a positive 
control at $100 \mu \mathrm{M}$. Isolated compounds $(\mathbf{1 - 4 , 7 - 8})$ were tested for their BACE1 inhibitory activity at $100 \mu \mathrm{M}$ (final concentration).

Acknowledgements We would like to thank Ms. Tamami Koseki (MS spectra) and Ms. Shoko Yamada (NMR spectra), Instrumental analysis center in Meiji Pharmaceutical University for measuring the MS or NMR spectra.

\section{References}

1. Parra F, Pérez-Nasser N, Lira R et al (2008) Population genetics and process of domestication of Stenocereus pruinosus (Cactaceae) in the Tehuacán Valley, México. J Arid Environ 72:19972010. https://doi.org/10.1016/j.jaridenv.2008.06.007

2. Casas A, Caballero-Mellado J, Valiente-Banuet A (1999) Use, management and domestication of columnar cacti in South-central Mexico: a historical perspective. J Ethnobiol 19:71-95

3. Djerassi C, Liu LH, Farkas E et al (1955) Terpenoids. XI.1 investigation of nine cactus species. Isolation of two new triterpenes, stellatogenin and machaeric acid2. J Am Chem Soc 77:12001203. https://doi.org/10.1021/ja01610a033

4. Kinoshita K, Akiba M, Saitoh M et al (1998) Antinociceptive effect of triterpenes from cacti. Pharm Biol 36:50-55. https://doi. org/10.1076/phbi.36.1.50.4614

5. Fujihara K, Takahashi K, Koyama K, Kinoshita K (2017) Triterpenoid saponins from Polaskia chichipe Backbg. and their inhibitory or promotional effects on the melanogenesis of B16 melanoma cells. J Nat Med. https://doi.org/10.1007/s11418-017-1082-9

6. Fujihara K, Koike S, Ogasawara Y et al (2017a) Inhibition of amyloid $\beta$ aggregation and protective effect on SH-SY5Y cells by triterpenoid saponins from the cactus Polaskia chichipe. Bioorg Med Chem 25:3377-3383. https://doi.org/10.1016/j.bmc.2017.04.023

7. Kakuta K, Baba M, Ito S et al (2012) New triterpenoid saponins from cacti and anti-type i allergy activity of saponins from cactus. Bioorg Med Chem Lett 22:4793-4800. https://doi.org/10.1016/j. bmcl.2012.05.058

8. Kakuta K, Koike T, Kinoshita K et al (2012) New triterpenoid saponins from Stenocereus eruca. Heterocycles 85:1377-1392. https://doi.org/10.3987/COM-12-12458

9. Okazaki S, Kinoshita K, Ito S et al (2011) Triterpenoid saponins from Echinopsis macrogona (Cactaceae). Phytochemistry 72:136-146. https://doi.org/10.1016/j.phytochem.2010.10.004

10. Okazaki S, Kinoshita K, Koyama K et al (2007) New triterpene saponins from Stenocereus eruca (Cactaceae). J Nat Med 61:2429. https://doi.org/10.1007/s11418-006-0014-x

11. Imai T, Okazaki S, Kinoshita K et al (2006) Triterpenoid saponins from cultural plants of Stenocereus stellatus (Cactaceae). J Nat Med 60:49-53. https://doi.org/10.1007/s11418-005-0004-4

12. Kinoshita K, Koyama K, Takahashi K et al (2000) A new triterpenoid saponin from Isolatocereus dumortieri. J Nat Prod 63:701703. https://doi.org/10.1021/np9903907

13. Zhang X, Zhang S, Yang Y et al (2019) Natural barrigenol-like triterpenoids: a comprehensive review of their contributions to medicinal chemistry. Phytochemistry 161:41-74. https://doi. org/10.1016/j.phytochem.2019.01.017

14. Bhandari P, Sendri N, Devidas SB (2020) Dammarane triterpenoid glycosides in Bacopa monnieri: a review on chemical diversity and bioactivity. Phytochemistry 172:112276. https://doi. org/10.1016/j.phytochem.2020.112276

15. Tagawa K, Kunishita T, Maruyama K et al (1991) Alzheimer's disease amyloid $\beta$-clipping enzyme (APP secretase): identification, purification, and characterization of the enzyme. Biochem Biophys Res Commun 177:377-387. https://doi.org/10.1016/0006291X(91)91994-N

16. Tischer E, Cordell B (1996) $\beta$-amyloid precursor protein. J Biol Chem 271:21914-21919. https://doi.org/10.1074/ jbc.271.36.21914

17. Sandberg A, Luheshi LM, Söllvander S et al (2010) Stabilization of neurotoxic Alzheimer amyloid- $\beta$ oligomers by protein engineering. Proc Natl Acad Sci USA 107:15595-15600. https://doi. org/10.1073/pnas.1001740107

18. Masters CL, Simms G, Weinman NA et al (1985) Amyloid plaque core protein in Alzheimer disease and Down syndrome. Proc Natl Acad Sci USA 82:4245-4249. https://doi.org/10.1073/ pnas.82.12.4245

19. Awasthi M, Singh S, Pandey VP, Dwivedi UN (2016) Alzheimer's disease: an overview of amyloid beta dependent pathogenesis and its therapeutic implications along with in silico approaches emphasizing the role of natural products. J Neurol Sci 361:256271. https://doi.org/10.1016/j.jns.2016.01.008

20. Velander P, Wu L, Henderson F et al (2017) Natural productbased amyloid inhibitors HHS public access author manuscript. Biochem Pharmacol 139:40-55. https://doi.org/10.1016/j. bcp.2017.04.004

21. Deshpande P, Gogia N, Singh A (2019) Exploring the efficacy of natural products in alleviating Alzheimer's disease. Neural Regen Res 14:1321-1329. https://doi.org/10.4103/1673-5374.253509

22. Le BuX, Rao PPN, Wang YJ (2016) Anti-amyloid aggregation activity of natural compounds: implications for Alzheimer's drug discovery. Mol Neurobiol 53:3565-3575. https://doi.org/10.1007/ s12035-015-9301-4

23. Li X, Cui J, Yu Y et al (2016) Traditional Chinese nootropic medicine Radix Polygalae and its active constituent onjisaponin B reduce $\beta$-amyloid production and improve cognitive impairments. PLoS ONE 11:1-19. https://doi.org/10.1371/journal.pone.01511 47

24. Khan MI, Shin JH, Kim MY et al (2020) Green tea seed isolated theasaponin E1 ameliorates AD Promoting neurotoxic pathogenesis by attenuating A $\beta$ peptide levels in SweAPP N2a cells. Molecules 25:2334

25. Tanaka T, Nakashima T, Ueda T et al (2007) Facile discrimination of aldose enantiomers by reversed-phase HPLC. Chem Pharm Bull 55:899-901. https://doi.org/10.1248/cpb.55.899

26. Bock K, Lundt I, Pedersen C (1973) Assignment of anomeric structure to carbohydrates through geminal $13 \mathrm{C}-\mathrm{H}$ coupling constants. Tetrahedron Lett 14:1037-1040. https://doi.org/10.1016/ S0040-4039(01)95898-8

27. Jia Z, Koike K, Nikaido T (1998) Major triterpenoid saponins from Saponaria officinalis. J Nat Prod 61:1368-1373. https://doi. org/10.1021/np980167u

28. Borel C, Gupta MP, Hostettmann K (1987) Molluscicidal saponins from Swartzia simplex. Phytochemistry 26:2685-2689. https:// doi.org/10.1016/S0031-9422(00)83572-4

29. Kunert O, Haslinger E, Schmid MG et al (2000) Three saponins, a steroid, and a flavanol glycoside from Achyrantes aspera. Monatshefte fur Chemie 131:195-204. https://doi.org/10.1007/PL000 10306

30. Melek FR, Miyase T, El-Gindi OD et al (1996) Saponins from Fangonia mollis. Phytochemistry 42:1405-1407

31. Wang X, Perumalsamy H, Kwon HW et al (2015) Effects and possible mechanisms of action of acacetin on the behavior and eye morphology of Drosophila models of Alzheimer's disease. Sci Rep. https://doi.org/10.1038/srep16127

32. Kemertelidze EP, Skhirtladze AV, Ganzera M (2017) Steroidal and Triterpenoid Glycosides from Roots of Digitalis ciliata. Chem Nat Compd 53:492-496. https://doi.org/10.1007/s1060 0-017-2029-9 
33. Li Q, Cao J, Yuan W et al (2017) New triterpene saponins from flowers of Impatiens balsamina L. and their anti-hepatic fibrosis activity. J Funct Foods 33:188-193. https://doi.org/10.1016/j. jff.2017.03.033

34. Rengifo Carrillo M, Mitaine-Offer AC, Miyamoto T et al (2017) Oleanane-type glycosides from Pittosporum tenuifolium "variegatum" and P. tenuifolium "gold star." Phytochemistry 140:166-173. https://doi.org/10.1016/j.phytochem.2017.04.013

35. Ye W, Liu X, Zhang Q et al (2001) Antisweet saponins from Gymnema sylvestre. J Nat Prod 64:232-235. https://doi. org/10.1021/np0004451

36. Rasoanaivo P, Multari G, Federici E, Galeffi C (1995) Triterpenoid diglucoside of Enterospermum pruinosum. Phytochemistry 39:251-253. https://doi.org/10.1016/0031-9422(94)00859-R

37. Harinantenaina L, Brodie PJ, Callmander MW et al (2012) Two antiproliferative saponins of Tarenna grevei from the Madagascar dry forest [1]. Nat Prod Commun 7:705-708. https://doi. org/10.1177/1934578x1200700604

38. Shaheen U, Ragab EA, Abdalla AN, Bader A (2018) Triterpenoidal saponins from the fruits of Gleditsia caspica with proapoptotic properties. Phytochemistry 145:168-178. https://doi. org/10.1016/j.phytochem.2017.11.007

39. Hariharan V, Rangaswami S (1970) Structure of saponins A and B from the seeds of achyranthes aspera. Phytochemistry 9:409-414. https://doi.org/10.1016/S0031-9422(00)85154-7

40. Ito A, Chai HB, Kardono LBS et al (2004) Saponins from the Bark of Nephelium maingayi. J Nat Prod 67:201-205. https://doi. org/10.1021/np030389e

41. Ye WC, Zhang QW, Liu X et al (2001) Oleanane saponins from Gymnema sylvestre Wen-Cai. Phytochemistry 53:893-899. https ://doi.org/10.1021/np0004451
42. Wu HB, Liu TT, Wang WS et al (2017) Oleanane-type saponins from the roots of ligulariopsis shichuana and their $\alpha$-glucosidase inhibitory activities. Molecules 22:4-11. https://doi.org/10.3390/ molecules22111981

43. Kinjo J, Suyama K, Nohara T (1995) Triterpenoidal saponins from dumasia truncata. Phytochemistry 40:1765-1767

44. Voutquenne L, Guinot P, Froissard C et al (2005) Haemolytic acylated triterpenoid saponins from Harpullia austro-caledonica. Phytochemistry 66:825-835. https://doi.org/10.1016/j.phyto chem.2005.02.009

45. Zebiri I, Haddad M, Duca L et al (2016) Zebiriosides A-L, oleanane saponins from the roots of Dendrobangia boliviana. Phytochemistry 130:262-272. https://doi.org/10.1016/j.phyto chem.2016.06.006

46. Dizes C, Gerald F, Lavaud C et al (1998) Harpuloside a triterpenoid saponin from harpullia ramiflora. Phytochemistry 48:1229-1232

47. Stevenson PC, Nyirenda SP, Veitch NC (2010) Highly glycosylated flavonoids from the pods of Bobgunnia madagascariensis. Tetrahedron Lett 51:4727-4730. https://doi.org/10.1016/j.tetle t.2010.07.013

48. Naiki H, Gejyo F (1999) [20] kinetic analysis of amyloid fibril formarion. Methods Enzymol 309:305-318

Publisher's Note Springer Nature remains neutral with regard to jurisdictional claims in published maps and institutional affiliations.

\section{Affiliations}

\section{Koji Fujihara ${ }^{1} \cdot$ Takuya Shimoyama $^{1} \cdot$ Ryo Kawazu $^{1} \cdot$ Hiroaki Sasaki $^{1} \cdot$ Kiyotaka Koyama $^{1} \cdot$ Kunio Takahashi $^{1}$. Kaoru Kinoshita' ${ }^{1}$}

1 Department of Pharmacognosy and Phytochemistry, Meiji

Pharmaceutical University, 2-522-1 Noshio, Kiyose-shi,

Tokyo 204-8588, Japan 